Florida A\&M University College of Law Scholarly Commons@ FAMU Law

Journal Publications

Faculty Works

1978

\title{
Reserved Water Rights, Indian Rights and the Narrowing Scope of Federal Jurisdiction: The Colorado River Decision
}

Robert H. Abrams

Florida A \& $M$ University College of Law, robert.abrams@famu.edu

Follow this and additional works at: http://commons.law.famu.edu/faculty-research Part of the Water Law Commons

Recommended Citation

Robert H. Abrams, Reserved Water Rights, Indian Rights and the Narrowing Scope of Federal Jurisdiction: The Colorado River Decision, 30 Stan. L. Rev. 1111 (1978)

This Article is brought to you for free and open access by the Faculty Works at Scholarly Commons @ FAMU Law. It has been accepted for inclusion in Journal Publications by an authorized administrator of Scholarly Commons @ FAMU Law. For more information, please contact linda.barrette@famu.edu. 


\title{
Reserved Water Rights, Indian Rights and the Narrowing Scope of Federal Jurisdiction: The Colorado River Decision
}

\author{
Robert H. Abrams*
}

In 1976, the United States Supreme Court decided Colorado River Water Conservation District v. United States, ${ }^{1}$ holding that principles of judicial administration relating to "contemporaneous exercise of concurrent jurisdictions"2 command that the federal courts abjure congressionally granted, previously attached jurisdiction of federal claims to reserved water rights. By establishing state courts as the primary forum for adjudicating all water rights within state boundaries, Colorado River dramatically extends state courts' control of reserved rights claims, including rights claimed by the federal government as trustee for American Indian lands withdrawn by treaty or other congressional action.

Unfortunately, Colorado River will have harmful consequences for proper determination of reserved rights claims. Although the decision did not abolish concurrent jurisdiction, it virtually assures adjudication of all claims in state courts, which will have strong incentives to discriminate against federal claims in favor of state and private uses. Any significant diminution of federal water rights hampers the proper development of federal lands and interferes with congressional policies. Further, the problems inherent in state adjudication of reserved water rights are especially acute when Indian claims are involved, because the states will give inadequate attention to the unique status and problems of the Indians.

* A.B. 1969, J.D. 1973, University of Michigan. Associate Professor of Law, Wayne State University.

1. 424 U.S. 800 (1976). Colorado River was decided with Akin v. United States

2. Id. at 817 . 
This Article explores the impact of Colorado River and examines critically the Court's choice to remit to state courts claims involving federally created Indian water rights. Part I of the Article traces the development of federal-state water law relations and analyzes the Colorado River decision in light of this development. ${ }^{3}$ Part II examines the jurisdictional implications of the decision and concludes that most, if not all, reserved rights cases will now be tried in state courts. Parts III and IV explore the problems of exclusive state control of these claims. Part III describes the justifications for a federal forum in reserved rights cases and suggests that the policies underlying the doctrine of protective jurisdiction be applied to preserve federal adjudication of reserved rights. Part IV discusses the special status of American Indians, concluding that this status warrants reconsideration of the Colorado River doctrine.

\section{The Colorado River Decision}

\section{A. Development of the Federal-State Relationship in Western Water Law}

During the 19th Century the arid West developed the doctrine of prior appropriation to govern water rights, rather than adopting the pure riparianism found throughout the East. In contrast to riparian emphasis on abutting owners' rights to reasonable use of undiminished stream flows, ${ }^{4}$ the prior appropriation system favors users who first divert water for beneficial use, regardless of proximity to the stream. ${ }^{5}$

Shortly after the Civil War, Congress recognized rights created by beneficial appropriation of water on public land. ${ }^{6}$ In 1877 , Congress passed the Desert Land Act, ${ }^{7}$ making state law the exclusive

3. For excellent surveys of the multifaceted federal-state relationship in western water law, see 2 R. Clark, WATERS AND WATER RightS $\S \S 100.1-107.3$ (1967); Morreale, FederalState Conflicts Over Western Waters-A Decade of Attempled "Clanifying Legislation", 20 RUTGERs L. REv. 423, 428-46 (1966).

4. See 7 R. ClaRK, supra note $3, \S 610$.

5. See 1 id $\S \S 4.1-.2$. The measure of rights varies markedly between the two systems. Riparian law limits usage by reference to what should be left in the water body for downstream use, while appropriative rights are measured by what has been taken in the past. See 7 id. $\$ 611$.

6. Act of July 26,1866 , ch. $262, \S 9,14$ Stat. 253 (current version at 30 U.S.C. $\S 51$ and 43 U.S.C. $\$ 661$ (1970), as amended by Act of Oct. 21, 1976, Pub. L. No. 94-579, tit. VII, $\S 706$ (a), 90 Stat. 2793); Act of July 9, 1870, ch. 235, § 17, 16 Stat. 218 (current version at 30 U.S.C. $\$ 52$ and 43 U.S.C. $\$ 661$ (1970), as amended by Act of Oct. 21, 1976, Pub. L. No. 94-579, tit. VII, § 706(a), 90 Stat. 2793). The public domain consists of federally owned land held open for settlement. Land devoted to other federal purposes such as national parks or military bases is described as withdrawn or reserved land.

7. Act of Mar. 3,1877 , ch. 107, 19 Stat. 377 (current version at 43 U.S.C. $\S \S 321-339$ (1970)). 
source for obtaining appropriative water rights on public lands. ${ }^{8}$ The Act thus severed water rights from property rights, which federal law still governed. ${ }^{9}$

Although federal and state interests coincided in establishment of a unified prior appropriation system, the governments have occasionally disagreed about ownership and management of unappropriated waters on federal lands. ${ }^{10}$ One important area of dispute has involved federal claims of reserved water rights_rights that vest in the federal government when land is withdrawn from the public domain and reserved for a specific federal purpose. ${ }^{11}$ The Supreme Court has always upheld federal claims to reserved water rights and has tacitly accepted the continuing federal interest in unappropriated waters of the public domain under the doctrine of Winters $v$. United States. ${ }^{12}$

This judicial vindication of federal claims has been a source of substantial frustration to the states for several reasons. First, recognition of federal reserved rights restricts the exercise of state sovereignty and in some instances preempts provisions of state constitutions or statutes. ${ }^{13}$ Second, these rights interfere with efficient operation of state prior appropriation systems. Because federal rights can arise by withdrawal of public domain lands without any physical appropriation and application to a beneficial use, ${ }^{14}$ other water users may be unable to ascertain the amount of unappropriated water. State law appropriators acquiring rights after a federal

8. See, e.g., California Ore. Power Co. v. Beaver Portland Cement Co., 295 U.S. 142, $163-64$ (1935).

9. See Twin Falls Salmon River Land \& Water Co. v. Caldwell, 272 F. 356, 357 (9th Cir. 1921), aff 266 U.S. 85 (1924): "The relation of the federal government to the state government in the reclamation of desert lands arises out of the fact that the federal government owns the lands, and Congress is invested by the Constitution with the power of disposing of the same, while the state has been given jurisdiction to provide for the appropriation and beneficial use of the waters of the state which necessarily includes a use for the reclamation of such lands."

10. See 2 R. CLARK, supra note $3, \S 102.3$.

11. See note 6 supra.

12. 207 U.S. 564 (1908). Winters involved reservation of nonnavigable waters by withdrawal from the public domain for use as an Indian reservation. Cf. Cappaert v. United States, 426 U.S. 128 (1976) (reservation of ground water by withdrawal from public domain for national monument use); Arizona v. California, 373 U.S. 546 (1963) (reservation of navigable water by withdrawal from public domain for Indian reservation, wildlife refuges and national recreation areas); FPC v. Oregon (Pelton Dam), 349 U.S. 435 (1955) (recognition of federal proprietary interest in waters on reserved lands); California Ore. Power Co. v. Beaver Portland Cement Co., 295 U.S. 142 (1935) (construing Desert Land Act of 1877).

13. See, e.g, Colo. Rev. Stat. § 37-92-102 (1973); N.D. Const. art. XVII, § 210; WYO. CoNST. art. VIII, $\S 1$.

14. See 2 R. CLARK, supra note $3, \S \S 102.1,8$. 
reservation receive only a defeasible property right until the extent of the reserved federal right is established. ${ }^{15}$ Although the Supreme Court recently ruled in Cappaert v. United States ${ }^{16}$ that the federal government should be awarded water sufficient to fulfill the purposes of the reservation, ${ }^{17}$ such a yardstick offers little predictability. ${ }^{18}$ Third, federal reserved rights have in the past frustrated state attempts to administer water law in their own courts.

Jurisdictional disputes have arisen continually because claimants of federal reserved rights seldom have been amenable to state court adjudication while the states' own interests favor the state forum. In recent years, however, the scope of state jurisdiction has increased. After passage of the McCarran Amendment in $1952,{ }^{19}$ many federal claimants were unable to argue that sovereign immunity necessitated federal jurisdiction. The Colorado River decision further limits the ability of federal claimants to resist state court adjudication. ${ }^{20}$

\section{B. The Colorado River Setting and Decision}

The Colorado River litigation involved federal lands reserved from the public domain in Colorado. Some of the reserved lands were devoted to specific federal uses while some of the reserved lands were Indian reservations, for which the United States claimed water rights as trustee. ${ }^{21}$ In 1972, prior to the institution of any state court action in Colorado Water Division No. $7,{ }^{22}$ the United States filed suit ${ }^{23}$ in

15. In the past, quantifications have been so rare that few standards exist to guide determination of an award. See, e.g., Arizona v. California, 373 U.S. 546, 600-01 (1963) (upholding without citation of authority the method of quantification chosen by the Special Master).

16. 426 U.S. 128 (1976).

17. Id. at 141 .

18. See Ranquist, The Winters Doctrine and How It Grew: Federal Reservation of Rights to the Use of Water, 1975 B.Y.U. L. REv. 639, 659-62. See also Abrams, Implied Reservation of Water Rights in the Aftermath of Cappaert v. United States, 7 ENVT'L L. REP. 50043, 50052 (1977).

19. Department of Justice Appropriation Act, 1953, Pub. L. No. 495, $\$ 208,66$ Stat. 560 (1952) (current version at 43 U.S.C. $\$ 666(1970)$ ). See notes $33-54$ infra and accompanying text.

20. See text accompanying notes 105-31 infra.

21. Other lands involved were reserved for diverse national purposes, including a national park, national monuments and several reclamation projects. See United States v. Akin, 504 F.2d 115, 116-17 (10th Cir. 1974), rev'd in part sub nom. Colorado River Water Conservation Dist. v. United States, 424 U.S. 800 (1976). The claims for reclamation were based on state law appropriation. United States v. Akin, Civil No. 4497 (D. Colo. July 30, 1973).

22. Some confusion exists regarding the date of institution of the state court proceedings in Water Division No. 7. The date most often mentioned is January 3,1973-some 6 weeks after filing the suit in federal court. United States v. Akin, 504 F.2d 115, 116-17 (10th Cir. 1974), rev'd in part sub nom. Colorado River Water Conservation Dist. v. United States, 
federal district court seeking a declaration of all its water rights in the region. ${ }^{24}$ The federal government was then served as a defendant in the Colorado water court ${ }^{25}$ in a suit involving rights in the same waters claimed in the federal action. The district court subsequently granted a motion to dismiss the federal suit based on the abstention doctrine and reasons of "comity." 26 The United States Court of Appeals for the Tenth Circuit reversed, ${ }^{27}$ and the Supreme Court granted certiorari. ${ }^{28}$

Writing for a majority of six, Justice Brennan reversed the court of appeals and reinstated the district court's dismissal of the suit. ${ }^{29}$ In

424 U.S. 800,806 (1976). The confusion is likely a result of the continuous adjudication concept inherent in the Colorado statutory scheme. See note 25 infra.

23. Subject matter jurisdiction was properly invoked under 28 U.S.C. $\S 1345$ (1970). United States v. Akin, 504 F.2d 115, 117-19 (10th Cir. 1974), affd in relevant part sub nom. Colorado River Water Conservation Dist. v. United States, 424 U.S. 800, 809 (1976).

24. The claim asserted both reserved rights and rights created by state law. See note 21 supra.

25. The United States previously had been served and had become a party to state court water adjudications in other Colorado Water Districts. See 424 U.S. at 820 . The state law involved in these suits was Colorado's Water Rights Determination and Administration Act of 1969, Colo. REv. STAT. \$§ 37-92-101 to -602 (1973 \& Supp. 1976), which divides the state into seven water divisions based on natural drainage basins. Id. §37-92-101. Each division has a separate water judge who is given exclusive jurisdiction over "water matters" within the division. Id. § 37-92-203(1). But of. Larrick v. District Court, 177 Colo. 237, 240, 493 P.2d 647, 649-50 (1972) (jurisdiction of water judges extends only to "water matters" specified by statute). The water judges continuously adjudicate the rights claimed, using a coordinate system of water referees. CoLo. REv. STAT. \$§ 37-92-203(4) to -203(7), -301(2), -302 to -303 (1973 \& Supp. 1976). Water rights determinations are recorded in each district, id. $\$$ 37-92-302 to -303, and are enforced by the State Engineer, id. $\S \S 37-92-202,-301(1)$. This official must also compile a master tabulation of appropriative priorities in each water district. Id. § 37-92-401. Claimants who believe their rights have been omitted from the tabulation must object, $i d \S 37-92-401$ (3), (5), or risk the effective abandonment of their claim of right, id. $\S 37-92-402$. Because the statute has been amended recently, it is uncertain whether the concept of abandonment effectuated by the statutory scheme is intended to apply to federal reserved rights not actually the subject of statutory adjudication. Nor is it clear that a construction eliminating reserved rights would be constitutionally permissible.

26. See United States v. Akin, 504 F.2d 115, 117 (10th Gir. 1974), rev'd in part sub nom. Colorado River Water Conservation Dist. v. United States, 424 U.S. 800 (1976). The federal district court granted the motion in an unreported oral opinion. 424 U.S. at 806.

27. United States v. Akin, 504 F.2d 115 (10th Cir. 1974), rev'd in part sub nom. Colorado River Water Conservation Dist. v. United States, 424 U.S. 800 (1976).

28. 421 U.S. 946 (1975).

29. Colorado River Water Conservation Dist. v. United States, 424 U.S. 800 (1976). Justice Brennan was joined by the Chief Justice and Justices White, Marshall, Powell, and Rehnquist. Justice Stewart dissented in an opinion joined by Justices Blackmun and Stevens. Id. at 821. Justice Stevens submitted a separate dissenting opinion. Id. at 826 . The Colorado River decision has been favorably discussed in Elliot and Balcomb, Deference to State Courts in the Adjudication of Reserved Water Rights, 53 DEN. L.J. 643 (1976). For a careful analysis of Colorado River's impact on federal jurisdictional policy generally, see Comment, Federal 
his opinion he first recognized that the McCarran Amendment mandated concurrent jurisdiction for determinations of federal reserved rights held on behalf of Indians. ${ }^{30}$ Although he reasoned that the abstention doctrine was inapplicable in this case, ${ }^{31}$ he concluded that the action should be dismissed because principles of judicial administration suggested that Colorado's comprehensive system for adjudication of water rights could best determine federal claimants' rights. ${ }^{32}$

\section{Concurrent jurisdiction under the McCarran Amendment.}

Justice Brennan held that the McCarran Amendment established concurrent jurisdiction for most claims involving federal reserved water rights. ${ }^{33}$ The Amendment allows the federal government to be sued in state court when government-owned water rights are at issue. ${ }^{34}$ The passage of the Amendment was aimed at encouraging judicial and administrative efficiency by consolidating all water rights controversies in a single forum. Legislative history suggests the Amendment was meant to grant permissive state jurisdiction rather than to remove the federal jurisdictional grant of 28 U.S.C. $\S 1345 .^{35}$

Court Stays and Dismissals in Deference to Parallel State Court Proceedings: The Impact of Colorado River, 44 U. CHI. L. REv. 641 (1977).

30. 424 U.S. at 809.

31. Id at 813 .

32. Id. at $819-20$.

33. As now codified, the McCarran Amendment reads: "(a) Consent is given to join the United States as a defendant in any suit (1) for the adjudication of rights to the use of water of a river system or other source, or (2) for the administration of such rights, where it appears that the United States is the owner of or is in the process of acquiring water rights by appropriation under State law, by purchase, by exchange, or otherwise, and the United States is a necessary party to such suit. The United States, when a party to any such suit, shall (1) be deemed to have waived any right to plead that the State laws are inapplicable or that the United States is not amenable thereto by reason of its sovereignty, and (2) shall be subject to the judgments, orders, and decrees of the court having jurisdiction, and may obtain review thereof, in the same manner and to the same extent as a private individual under like circumstances: Provided, That no judgment for costs shall be entered against the United States in any such suit. (b) Summons or other process in any such suit shall be served upon the Attorney General or his designated representative. (c) Nothing in this section shall be construed as authorizing the joinder of the United States in any suit or controversy in the Supreme Court of the United States involving the right of States to the use of the water of any interstate stream." 43 U.S.C. $§ 666$ (1970).

34. The Senate Report on the McCarran Amendment stated: "The purpose of the proposed legislation, as amended, is to permit the joinder of the United States as a party defendant in any suit for the adjudication of rights to the use of water . . . ." S. REP. No. 755, 82d Cong., 1st Sess. 2 (1951) (emphasis added). Joinder of the United States was impermissible except in cases involving the general adjudication of "all the rights of various owners on a given stream." Id. at 19. See United States v. District Court for Eagle County, 401 U.S. 520, 525 (1971); Dugan v. Rank, 372 U.S. 609, 617-19 (1963).

35. That section, which grants federal jurisdiction in cases where the federal govern- 
Earlier Court decisions held that state jurisdiction was permissible in cases involving general state adjudication of all the rights of the owners on a given stream. ${ }^{36}$ Most importantly, the 1971 decisions in United States v. District Court for Eagle County ${ }^{37}$ and United States v. District Court for Water Division No. $5^{38}$ expressly held that Colorado law ${ }^{39}$ established such a system of general adjudication and that McCarran Amendment consent to state jurisdiction included reserved water rights claims. ${ }^{40}$ The Court in Colorado River extended permissive state jurisdiction to encompass Indian reserved rights protected by the federal government as trustee ${ }^{41}$ while simultaneously making state courts the preferred forum for all adjudications of reserved rights.

Colorado River's enlargement of permissive jurisdiction relied heavily on dictum in Eagle County which treated Indian reserved rights as indistinguishable from other reserved rights. ${ }^{42}$ Justice Brennan also cited the Senate's rejection of an. exemption for Indian claims during consideration of the McCarran Amendment, ${ }^{43}$ concluding that Congress preferred a comprehensive determination of all federal reserved rights. ${ }^{44}$ The opinion found no merit in the government's claim that submission of Indian reserved rights to state court jurisdiction might violate the fiduciary duty the United States owed the Indians. ${ }^{45}$ Instead, the Court believed state law could adequately protect Indian interests. ${ }^{46}$ It added that no substantive In-

ment acts as plaintiff, provides: "Except as otherwise provided by Act of Congress, the district courts shall have original jurisdiction of all civil actions, suits or proceedings commenced by the United States, or by any agency or officer thereof expressly authorized to sue by Act of Congress." 28 U.S.C. § 1345 (1970).

36. See United States v. District Court for Water Div. No. 5, 401 U.S. 527 (1971); United States v. District Court for Eagle County, 401 U.S. 520 (1971); Dugan v. Rank, 372 U.S. 609 (1963).

37. 401 U.S. 520 (1971).

38. 401 U.S. 527 (1971).

39. See Colo. Rev. StaT. § 37-92-101 to -602 (1973 \& Supp. 1976).

40. United States v. District Court for Eagle County, 401 U.S. 520, 523-24 (1971). The Court emphatically rejected the government's argument that the McCarran Amendment did not embrace federal reserved rights. "[W] deal with an all-inclusive statute . . . which in $\$ 666(a)(1)$ has no exceptions and which, as we read it, includes appropriative rights, riparian rights, and reserved rights." Id. at 524.

41. 424 U.S. at 809-13.

42. Id. at 810 (citing United States v. District Court for Eagle County, 401 U.S. 520, 523-24 (1971)).

43. 424 U.S. at $811-12$ (citing S. REP. No. 775, 82d Cong., 1st Sess. 6-7, 67-68 (1951)).

44. 424 U.S. at 810-11 (citing S. REP. No. 775, 82d Cong., 1st Sess. 4-5 (1951)).

45. 424 U.S. at 812.

46. Id. 
dian claims were abridged by the change in forum ${ }^{47}$ and noted that reserved rights issues were federal questions ultimately reviewable by the Court. ${ }^{48}$

Careful examination of the Court's McCarran Amendment analysis reveals several weaknesses. For example, the opinion's conclusion that Congress intended to include Indian rights within the Amendment is poorly reasoned. Justice Brennan pointed to the Senate Judiciary Committee's rejection of a Department of the Interior letter recommending exemption of Indian water rights from the Amendment. ${ }^{49}$ His view was that omission of such an exemption in the final bill amounted to a rejection of special treatment for Indian water rights. This conclusion assumes Congress thought Indian water rights would be subject to state adjudication. The rejection of Interior's recommendation does not support that assumption, ${ }^{50}$ and Congress justifiably could have thought Indian rights exempt under principles of Indian law. ${ }^{51}$ Moreover, subsequent acts of Congress indicate hostility to state jurisdiction over Indian rights. ${ }^{52}$

The Court also noted Eagle County dictum which suggested no basis for different treatment of Indian reserved water rights. ${ }^{53}$ The obvious rejoinder is that the Eagle County Court avoided premature

47. Id. at 813 .

48. Id. (citing United States v. District Court for Eagle County, 401 U.S. 520, 526 (1971)).

49. 424 U.S. at 812 (citing S. REp. No. 775, 82d Cong., 1st Sess. 2, 7-8 (1951)).

50. Interior feared a general waiver might be construed as including rights Congress did not wish to waive and urged a limitation of the Amendment's scope to federal rights acquired under state law. The Department's letter contained a list of some federal rights, including Indian water rights, which might fall under a general waiver. S. REP. No. 755, 82d Cong., 1st Sess. 8 (1951). Congress' rejection of the rights limitation does not indicate whether it desired the broad construction or felt that the limitation was unnecessary.

51. States have no power to regulate Indian affairs except that which is specifically granted by Congress. See McClanahan v. Arizona State Tax Comm'n, 411 U.S. 164, 175 n.13 (1973).

52. The Senate report for 28 U.S.C. § 1362, a 1966 enactment which vests original jurisdiction in the federal courts for certain types of suits brought by Indian tribes, states that one reason for the act is the Indians' fear that state courts resolve their suits unfavorably. S. REP. No. 1507, 89th Cong., 2d Sess. 2 (1966). The report also credits the federal courts with "more expertise in deciding questions involving treaties with the Federal Government, as well as interpreting the relevant body of Federal law that has developed over the years." Id. Moreover, Congress enacted Act of Aug. 15, 1953, ch. 505, § 4, 67 Stat. 589 (current version at 28 U.S.C. $§ 1360$ (1970)), which further proves congressional hostility to state jurisdiction, since it granted certain states jurisdiction over disputes involving Indians if the states had jurisdiction over similar suits not involving Indians, but specifically prohibited state jurisdiction over Indian water rights, 28 U.S.C. $\$ 1360$. See Ranquist, supra note 18, at 702-05; Note, Adjudication of Indian and Federal Water Rights in the Federal Courts, 46 U. CoLO. L. REV. 555, 580-81 (1975).

53. 424 U.S. at 810 . 
decision of a subtle and potentially complex question rather than addressing it without aid of counsel or briefs. After Eagle County, even water rights experts remained uncertain whether the McCarran Amendment embraced Indian water rights adjudication. ${ }^{54}$ Thus, Justice Brennan's arguments supporting extension of the Eagle County decision lack the substantive base necessary to a major alteration of policy.

\section{Abstention doctrine.}

After concluding that concurrent jurisdiction existed, Justice Brennan rejected the district court's determination that the abstention doctrine warranted dismissal of the suit. ${ }^{55} \mathrm{He}$ examined each of the rationales for abstention-avoidance of unnecessary decision of a federal constitutional issue,$^{56}$ preference for state court determination of difficult and important issues of state law and policy ${ }^{57}$ and avoid-

54. See United States National Water Commission, Water Policies for the FurURE 478 (1973). The report stated: "The present law is somewhat uncertain on the adjudication of Indian water rights. . . . The only Supreme Court cases construing the McCarran Amendment, the Eagle County and Water Division No. 5 cases, did not involve Indian water rights. With the law in this state of uncertainty, the Commission believes that new, clarifying legislation is desirable." Id. (footnotes omitted). The Commission recommended the creation of exclusive federal jurisdiction in cases involving Indian water rights. See id. at 478-79.

55. 424 U.S. at 813-17. The abstention doctrine holds that in certain circumstances federal courts may decline to proceed though they have jurisdiction under the Constitution and the statutes. See generally C. WRIGHT, HANDBOOK ON THE LAW OF FedERAL CourTs $\S 52$ (3d ed. 1976). Justice Brennan's lengthy discussion of abstention tries to give some doctrinal clarity to the field.

Abstention is for Justice Brennan a very narrow exception to the "virtually unflagging obligation" of the federal courts to exercise their congressionally specified jurisdiction. See Allegheny Co. v. Frank Mashuda Co., 360 U.S. 185, 188-89 (1959). Moreover, Justice Brennan has embraced the "federal primacy" doctrine, which asserts that after Reconstruction the federal courts " ceased to be restricted tribunals of fair dealing between citizens of different states and became the primary and powerful reliances for vindicating every right given by the Constitution, the laws, and treaties of the United States." " Zwickler v. Koota, 389 U.S. 241, 247 (1967) (quoting F. FRANKFuRTER \& J. LANDIS, THE Business OF THE SUPREME COURT 65 (1927)) (emphasis added by the Court). Thus, it is not surprising that Colorado River so carefully eschews abstention. See 424 U.S. at 813-17. On the other hand, Justice Brennan's antipathy to renunciation of federal jurisdiction makes his Colorado Riveropinion all the more surprising. A plausible, though unsubstantiated possibility, is that Justice Brennan joined what would have been a 5-member majority on narrow grounds and thus ensured that the case would not be decided on broader abstention grounds, such as expanding the doctrine of Younger v. Harris, 401 U.S. 37 (1971). Subsequent developments have indicated that such an expansion of Younger could have been within the contemplation of the other members of the Colorado River majority. See note 61 infra.

56. See, e.g., Railroad Comm'n v. Pullman Co., 312 U.S. 496 (1941).

57. See, e.g., Louisiana Power \& Light Co. v. City of Thibodaux, 360 U.S. 25 (1959); Burford v. Sun Oil Co., 319 U.S. 315 (1943). 
ance of federal restraints on state criminal and similar proceedings ${ }^{58}$-and found each inapplicable to Colorado River. Justice Brennan correctly dismissed the first ${ }^{59}$ and third considerations; ${ }^{60}$ recognizing that neither federal constitutional issues nor state criminal or quasi-criminal proceedings were involved in the case. ${ }^{61}$

A more plausible, though ultimately unconvincing, ground for abstention was the second consideration, applicable in cases involving "difficult questions of state law bearing on policy problems of substantial public import whose importance transcends the result in the case then at bar."62 Colorado River clearly involved an important subject of state concern: water rights adjudication in an arid state. ${ }^{63}$ Early in this century the Court recognized that questions of efficient water use in the western states warranted special legal treatment, ${ }^{64}$

58. See, e.g., Trainor v. Hernandez, 431 U.S. 434 (1977); Huffman v. Pursue, Ltd., 420 U.S. 592 (1975); Younger v. Harris, 401 U.S. 37 (1971).

59. 424 U.S. at 814.

60. Id. at $816-17$.

61. At the time Colorado River was decided, the Younger doctrine precluded federal injunctive or declaratory intervention in ongoing state criminal or quasi-criminal proceedings. See, e.g., Huffman v. Pursue, Ltd., 420 U.S. 592, 607 (1975); Samuels v. Mackell, 401 U.S. 66, 69 (1971); Younger v. Harris, 401 U.S. 37 (1971). See also C. WRIGHT, supra note 55, § 52. The doctrine has since been expanded to prohibit federal intrusion into state proceedings "through which [the state] vindicates the regular operation of its judicial system," Juidice v. Vail, 430 U.S. 327, 335 (1977), or state actions "brought to vindicate important state policies," Trainor v. Hernandez, 431 U.S. 434, 444 (1977). Despite this broadening of the Younger doctrine, Justice Brennan's rejection of its applicability in Colorado River remains sound. His opinion suggests Youngerdoes not apply unless the federal relief sought would constitute intrusion into the state proceedings. 424 U.S. at 816-17. The concurrent federal suit in Colorado River was not a serious intrusion into state interests: The United States sought neither an injunction against state proceedings nor a declaration holding the Colorado statute invalid. One could argue, however, that the suit did involve a situation of great importance to the state, even if there was no allegation of intrusiveness. Absent the power to determine federal water rights in a drainage district, a Colorado Water Judge arguably has lost part of the ability to render a judgment encompassing all the rights in a stream. But this problem clearly does not justify interrupting the normal federal judicial process, even in the wake of the massive Youngerexpansion. See generally Redish, The Doctrine of Younger v. Harris: Deferenee in Search of a Rationale, 63 CORNELL L. REV. 463 (1978).

62. 424 U.S. at 814.

63. Justice Brennan noted: "It is probable that no problem of the Southwest section of the Nation is more critical than that of scarcity of water. As southwestern populations have grown, conflicting claims to this scarce resource have increased. To meet these claims, several Southwestern States have established elaborate procedures for allocation of water and adjudication of conflicting claims to that resource. . . . Id. at 804.

64. See Clark v. Nash, 198 U.S. 361 (1905). The Court noted: "The rights of a riparian owner in and to the use of the water flowing by his land are not the same in the arid and mountainous States of the West that they are in the States of the East. These rights have been altered by many of the Western States. . . for the very purpose of thereby contributing to the growth and prosperity of those States arising from mining and the cultivation of an otherwise valueless soil, by means of irrigation. This court must recognize the difference in 
foreshadowing the rationale for abstention in cases involving water rights. ${ }^{65}$ Thus, in Kaiser Steel Corp. v. W.B. Ranch Co. ${ }^{66}$ the Court ruled that a federal district court should stay its proceedings pending state adjudication of the meaning of "public use" in the New Mexico Constitution. ${ }^{67}$ The per curiam opinion in Kaiser called the issue novel and "of vital concern" to the state. ${ }^{68}$ In contrast, the federal suit in Colorado River involved a state's settled system for quantifying appropriation rights. ${ }^{69}$ The difficult legal issue in Colorado River was not a novel question of state law, but rather a federal question concerning the quantity of water reserved to the Indians. ${ }^{70}$

Justice Brennan noted that abstention might be warranted if review of a federal question would disrupt a state's efforts to establish a coherent policy to deal with a matter of substantial public concern. ${ }^{71}$ Although federal reserved claims might conflict with state law, "the mere potential for conflict" was insufficient to warrant staying federal proceedings. ${ }^{72}$ Justice Brennan's determination that potential conflict with state-created rights does not justify the suspension of federal proceedings represents a vigorous effort by the Court to limit termination of federal suits on abstention grounds. Because abstention decisions involve consideration of the state interest in state court

climate and soil, which render necessary these different laws in the States so situated." Id. at 370.

65. In Clark, which dealt with private condemnation in the context of irrigation rights, the Court showed a strong preference for deferring to state courts: "Where the use is asserted to be public, and the right of the individual to condemn land . . . is the result of some peculiar condition of the soil or climate, or other peculiarity of the state, where the right of condemnation is asserted under a state statute, we are always, where it can be done fairly, strongly inclined to hold with the state courts, when they uphold a state statute providing for such condemnation. The validity of such statutes may sometimes depend upon many different facts .... and the state courts may be assumed to be exceptionally familiar with them. ... [State courts] understand the situation which led to the demand for the enactment of the statute, and they also appreciate the results upon the growth and prosperity of the State, which in all probability would flow from a denial of its validity." Id. at 367-68.

66. 391 U.S. 593 (1968).

67. Id. at 594 .

68. Id.

69. 424 U.S. at 815 ; see note 25 supra.

70. See 424 U.S. at $815-16$.

71. Id. at 814. See Alabama Pub. Serv. Comm'n v. Southern Ry., 341 U.S. 341, 349-50 (1951); Burford v. Sun Oil Co., 319 U.S. 315, 333-34 (1943); C. WRIGHT, supra note $55, \S 52$.

72. 424 U.S. at 816 (citing Meredith v. Winter Haven, 320 U.S. 228 (1943); Kline v. Burke Constr. Co., 260 U.S. 226 (1922); McClellan v. Carland, 217 U.S. 268 (1910)). "The potential conflict here, involving state claims and federal claims, would not be such as to impair impermissibly the State's effort to effect its policy respecting the allocation of state waters. Nor would exercise of federal jurisdiction here interrupt any such efforts by restraining the exercise of authority vested in state officers." 424 U.S. at 816. 
proceedings, this rejection of abstention in Colorado River implies that the nature of the state interest should not be dispositive of the important issues presented in selecting the appropriate forum for determination of reserved rights claims.

\section{3. "Judicial administration" dismissal.}

After deciding abstention doctrine was inapplicable, Justice Brennan held that considerations of "wise judicial administration" justified dismissal of the Colorado River federal suit. ${ }^{73}$ His opinion offered precedents for four types of considerations which might warrant such a dismissal: ${ }^{74}$ (1) the rule governing in rem and quasi-inrem actions that grants exclusive jurisdiction to the court that first obtains custody of the property; ${ }^{75}$ (2) inconvenience of the federal forum; ${ }^{76}$ (3) avoidance of piecemeal litigation; ${ }^{77}$ and (4) the sequence in which jurisdiction was obtained in the two forums. ${ }^{78} \mathrm{He}$ explicitly found the first and third factors present in Colorado River, ${ }^{79}$ and listed

73. 424 U.S. at 818. Justice Brennan called the circumstances permitting dismissal because of judicial administration "exceptional" and "considerably more limited than the circumstances appropriate for abstention." Id. Unlike abstention doctrine, dismissal for reasons of "wise judicial administration" does not involve the "weightier considerations of constitutional adjudication and state-federal relations." Id. The fundamental considerations underlying the policy of wise judicial administration include the conservation of judicial resources and the comprehensive disposition of litigation. Id. at 817 (quoting Kerotest Mfg. Co. v. G-O-Two Fire Equip. Co., 342 U.S. 180, 183 (1952)). Unlike Justice Brennan, Professor Wright classifies these examples as yet another type of abstention, "ordered merely to serve the convenience of the federal courts." See C. WRIGHT, supra note 55, § 52 .

74. He noted that no single factor was "necessarily determinative." 424 U.S. at 818. Instead, "a carefully considered judgment taking into account both the obligation to exercise jurisdiction and the combination of such factors counselling against that exercise is required." Id. at 818-19.

75. Id. at 818 (citing Donovan v. City of Dallas, 377 U.S. 408, 412 (1964) (dictum); Princess Lida v. Thompson, 305 U.S. 456, 466 (1939)); see Pennsylvania Gen. Cas. Co. v. Pennsylvania ex rel. Schnader, 294 U.S. 189, 195 (1935); C. WRIGHT, supra note 55, § 52. A concern for avoiding inconsistent dispositions and the litigation that might ensue is expressed in the Federal Anti-Injunction Statute, 28 U.S.C. $\$ 2283$ (1970), which permits a federal court to grant an injunction to stay a state court proceeding "where necessary in aid of its jurisdiction." Id. See Kline v. Burke Constr. Co., 260 U.S. 226, 229, 235 (1922); Hyde Constr. Co. v. Koehring Co., 388 F.2d 501 (10th Cir.), cert. denied, 391 U.S. 905 (1968).

76. 424 U.S. at 818 (citing Gulf Oil Corp. v. Gilbert, 330 U.S. 501 (1947)).

77. 424 U.S. at 818 (citing Brillhart v. Excess Ins. Co., 316 U.S. 491,495 (1942)).

78. 424 U.S. at 818 (citing Pacific Live Stock Co. v. Oregon Water Bd., 241 U.S. 440, 447 (1916)).

79. 424 U.S. at 819-20. Justice Brennan never explicitly addressed the second factor-convenience-but he may have impliedly done so in alluding to the distance between the federal court and Division No. 7 and the resulting impracticality of federal jurisdiction. See notes 99-102 infra and accompanying text. He also failed to explicitly discuss the fourth factor-the order of establishing jurisdiction-though he may have been referring to it when he declared that the federal suit was effectively "antedated" by the state court proceeding, 
four other administrative considerations present in this case: ${ }^{80}(1)$ the absence of any federal district court proceedings beyond the filing of the complaint; (2) extensive involvement of state water rights involving 1,000 sued defendants; (3) the 300-mile distance between the federal court in Denver and the state court in Durango; and (4) the federal government's participation in state water rights proceedings in other parts of Colorado. Close inspection suggests, however, that his findings were based on a number of misunderstandings about the nature of the state proceedings.

Exclusive property jurisdiction and avoiding piecemeal litigation. Justice Brennan linked the two considerations of exclusive jurisdiction for in rem and quasi-in-rem jurisdiction and the avoidance of piecemeal litigation. He perceived in the McGarran Amendment a clear federal policy favoring avoidance of piecemeal adjudication of water rights in a river system, ${ }^{81}$ viewing this policy as "akin" to that underlying the rule of exclusive jurisdiction in actions in rem and quasi-in-rem. ${ }^{82}$ By joining these two considerations, he apparently sought to overcome the Amendment's silence about the proper forum. ${ }^{83}$ Even if one accepts the somewhat loose manner in which he linked the underlying policies of the general rule regarding property jurisdiction and the McCarran Amendment, more fundamental objections remain. ${ }^{84}$

First, the exclusive jurisdiction rule used in property actions is inapplicable to this case. As Justice Stewart's dissent pointed out, the rule only applies "when exclusive control over the subject matter

because the latter was merely part of a continuing state adjudication. 424 U.S. at 819-20. It is worth noting that Justice Brennan developed this "antedating jurisdiction" argument sua sponte. The brief of the Colorado River Water Conservation District failed to argue that the continuous adjudication aspect of the Colorado Act, CoLo. REv. STAT. \$§ 37-92-101 to -602 (1973 \& Supp. 1976), gave the state suit prior attachment of jurisdiction of the claims in issue. See Brief for Petitioner.

80. 424 U.S. at 820 .

81. Id. at 819 .

82. Id. The dissent argued that Justice Brennan could invoke the rule of exclusive jurisdiction in rem only through reasoning by analogy; the rule itself had no precedential value. Further, a major policy behind the rule-avoiding piecemeal litigation-would not be served by its application to the facts of this case, because courts in both forums would use a separate procedure to determine reserved rights in any event. Id. at 823-25 (Stewart, J., dissenting).

83. See note 33 supra.

84. In interpreting the meaning of the McCarran Amendment and other acts affecting western water rights, platitudes regarding state sovereignty and the role of states in water adjudication are often misleading. The intense political struggles which accompany these enactments have led some authorities to dismiss such language as "boilerplate" or "political ritual". Morreale, supra note 3, at 456; see Sax, Problems of Federalism in Reclamation Law, 37 U. CoLo. L. REv. 49, 80 (1964). 
is necessary to effectuate a court's judgment." ${ }^{\text {85 }}$ The federal district court in Colorado River did not need control of the river in order to ascertain federal reserved rights. ${ }^{86}$ The questions of federal law before the Court concerned only the existence of such rights along with their scope and effective date. ${ }^{87}$

Second, federal adjudication of the Indian claims would not create piecemeal litigation. Unlike the prior appropriation claims of other parties to the state suit, determination of Indian and other reserved rights turned not on actual diversion and beneficial use but rather on the federal government's original intent to reserve a certain amount of water to support federal and Indian lands. ${ }^{88}$ Thus, a determination of Indian reserved rights in state court would require separate proceedings prior to the overall adjudication of rights in the river system. ${ }^{89}$ Because virtually the same process of separate adjudication of reserved rights would take place in either forum, Justice Brennan's assertion that federal litigation of the Indian rights would create piecemeal litigation appears to have little merit. ${ }^{90}$ Moreover, a final judgment by either court almost certainly would be given res

85. 424 U.S. at 822 (Stewart, J., dissenting). For example, federal courts generally do not exercise diversity jurisdiction when it is available in probate proceedings. See Waterman v. Canal-Louisiana Bank \& Trust Co., 215 U.S. 33 (1909); Byers v. McAuley, 149 U.S. 608 (1893); Hook v. Payne, 81 U.S. (14 Wall.) 252 (1872). See also P. BAtoR, P. Mishkin, D. SHAPIRO \& H. WECHSLER, HART \& WECHSLER'S THE FEDERAL COURTS AND THE FEDERAL SYSTEM 1186 (2d ed. 1973). This renunciation of jurisdiction has been based on several theories-deference to pre-existing state jurisdiction in rem, incomplete diversity among all interested parties and exclusivity of state court jurisdiction over probate matters. See id. While the precise scope of this renunciation is difficult to define, its purpose is to consolidate all claims against the estate in a forum capable of adjudicating the potentially conflicting demands of claimants. The rationale underlying this renunciation of diversity jurisdiction is thus analogous to the perceived intent of the McCarran Amendment's consent to inclusion of federal rights claims in general state adjudications. In the probate context, however, federal courts are allowed to exercise jurisdiction in suits against the estate or other claimants, but only to the extent that the suit seeks a determination of the validity of the claim, and "the federal court does not interfere with the probate proceedings or assume general jurisdiction of the probate or control of the property in custody of the state court." Markham v. Allen, 326 U.S. 490, 494 (1946); see Byers v. McAuley, 149 U.S. 608 (1893); P. BatoR, P. Mishkin, D. SHAPIRO \& H. WECHSLER, supraat 1186 . Federal adjudication, limited to a determination of the scope of federal rights, could be conducted with a similar lack of interference in state court adjudications. See notes 86-91 infra and accompanying text. Such a coordination of adjudicative roles would allow adequate protection of federal interests and a deference to Indians' perception of state court hostility, without violating the McCarran Amendment's policy in favor of general state adjudication of water rights.

86. 424 U.S. at 822 (Stewart, J., dissenting).

87. Id.

88. Id. at 824-25.

89. Id.

90. As Justice Stewart observed in his dissent, "[w]hether the virtually identical separate proceedings take place in a federal court or a state court, the adjudication of the claims 
judicata effect by the other, making conflicting dispositions leading to further litigation unlikely. ${ }^{91}$

Absence of federal proceedings. Justice Brennan next pointed to the lack of proceedings in federal district court as another reason to dismiss the suit. ${ }^{92}$ Although lack of federal proceedings of substance on the merits serves as a benchmark under one type of abstention, ${ }^{93}$ he cited no precedent for its application in Colorado River. As the dissent noted, the lack of proceedings merely signified the speed with which the district court had granted dismissal. ${ }^{94}$

Extensive involvement of state water rights. Although 1,000 defendants had been named in the federal suit, complex multiple party litigation involving extensive state water rights was not inevitable. Once federal jurisdiction attached over the reserved rights claim, the federal court could simply have decided the priority date of the federal claims and the quantity of water to be accorded them. ${ }^{95}$ Resolution of the federal question did not require the federal court to declare the relative rights of any subsequent state law appropriators or those of any prior state law appropriators. ${ }^{96}$ Although jurisdiction to hear those cases would be allowed by the doctrine of pendent jurisdiction, ${ }^{97}$ the district court could have declined to decide these issues. ${ }^{98}$ Thus, the specter of the federal court replacing the Colorado courts as the primary arbiter of the prior appropriation system was largely illusory.

will be neither more nor less 'piecemeal.' "Id. at 825 . See Comment, supra note 29, at 674-76. But see note 187 infra.

91. A state court would be bound by a prior federal court determination by operation of the supremacy clause, U.S. CoNST. art. VI. A federal court is statutorily required to respect state judgments in accord with 28 U.S.C. $\S 1738$ (1970). complaint.

92. 424 U.S. at 820 . No proceedings had occurred, except for the filing of the

93. See Hicks v. Miranda, 422 U.S. 332, 349 (1975) ("[W] ings are begun against the federal plaintiffs after the federal complaint is filed but before any proceedings of substance on the merits have taken place in the federal court, the principles of Younger v. Harris should apply in full force."). Justice Brennan specifically rejected the possibility of applying the Younger doctrine to Colorado River. See 424 U.S. at 816-17.

94. See 424 U.S. at 823 n.6 (Stewart, J., dissenting).

95. See text accompanying note 87 supra.

96. See text accompanying notes 87-89 supra.

97. See UMW v. Gibbs, 383 U.S. 715 (1966); Hurn v. Oursler, 289 U.S. 238 (1933); C.

WRIGHT, supra note 55, § 14. See also Hagans v. Lavine, 415 U.S. 528 (1974).

98. See UMW v. Gibbs, 383 U.S. 715, 726 (1966). 
Distance between the courts. The Court noted the 300-mile distance between the center of Water Division No. 7 in Durango and the federal district court in Denver, ${ }^{99}$ apparently considering this a significant inconvenience for efficient adjudication. In contrast, the dissent concluded that 300 miles is not great, given modern transport. ${ }^{100}$ Moreover, the federal district court had express statutory authority to sit in Durango, ${ }^{101}$ making it potentially as convenient a forum as the state court which sits there permanently. ${ }^{102}$

Federal involvement in earlier Colorado proceedings. Finally, Justice Brennan pointed to earlier federal participation without objection in similar Colorado water adjudications. ${ }^{103}$ But the Court was unclear why previous federal participation in state court supported the dismissal of the issue from federal court. As the dissent reprovingly observed, the government retained its right to bring suit in federal court, unless the Court was creating a new type of waiver. ${ }^{104}$

\section{Relegation of Reserved Rights Glaims to State Courts: The Jurisdictional ConseQuence OF Colorado River}

The Court's decision in Colorado River represents a substantial contraction of federal jurisdiction. Although the Court technically did not abolish federal concurrent jurisdiction over reserved rights claims, ${ }^{105}$ the opinion reaches this result in effect by dictating federal dismissal in deference to the state forum in virtually every case ${ }^{106}$ where a comprehensive state system exists for adjudication of water rights. ${ }^{107}$ As the impact of Colorado River becomes more widely recog-

99. See 424 U.S. at 820.

100. Id. at 824 n.6 (Stewart, J., dissenting). Justice Stewart also doubted that live testimony by water district residents would be required. Id.

101. See 28 U.S.C. $§ 85$ (1970). Justice Stewart notes this possibility in his dissent. See 424 U.S. at 824 n.6 (Stewart, J., dissenting).

102. The authority which the majority opinion cited on the question of convenience, Gulf Oil Corp. v. Gilbert, 330 U.S. 501 (1947), see 424 U.S. at 818, actually provided scant support. Gilbert presented a far more substantial convenience interest and, more important, a choice between federal forums. Choosing one over the other thus did not impinge upon the federal courts' "unflagging obligation" to exercise the jurisdiction provided by Congress. See 424 U.S. at 817.

103. 424 U.S. at 820.

104. Id. at 824 n.6 (Stewart, J., dissenting).

105. See id. at 807-09; notes 33-35 supra and accompanying text.

106. If none of the parties to the federal proceeding were to move for dismissal, it presumably would not occur. States and private appropriators, however, are likely to seek dismissal consistently.

107. See 424 U.S. at 819-20; United States v. District Court for Eagle County, 401 
nized, state legislatures will likely respond by conforming state water rights adjudication proceedings to the Colorado model. ${ }^{108}$ As this occurs, remaining routes of access to federal adjudication will be through removal jurisdiction or certiorari review by the Supreme Court. Unfortunately, neither of these routes is an attractive alternative to the exercise of congressionally authorized original jurisdiction.

\section{A. The Future of State Adjudication Systems}

Assured by Colorado River that state "general adjudication" proceedings will be the primary forum for all water disputes, western states have strong incentives to pass statutes which will allow them to assume jurisdiction over the vital question of water distribution. Each of the prior appropriation states has already established a system of special proceedings to adjudicate water rights disputes. ${ }^{109}$ If any of these state systems fall short of the Eagle County "general adjudication" requirement, ${ }^{110}$ the Colorado system is available as a paradigm. Because of the close relationship between water rights and economic development, ${ }^{111}$ each state has an interest in establishing a single forum to adjudicate all claims in a unitary proceeding. Further, states have strong selfish reasons to construe the scope of federal reserved rights narrowly, since these rights clash directly with the prior appropriation system. ${ }^{12}$ To the extent that state legislatures conclude that important state interests will receive a more favorable hearing in state court, systems of "general adjudication" are likely to be adopted.

\section{B. The Decline of Removal Jurisdiction}

In the Eagle County decisions, the Court allowed state water rights claimants to choose the state forum ${ }^{113}$ without considering whether the federal government could successfully seek removal of the action to the federal courts. ${ }^{14}$ In the wake of Colorado River, removal ap-

U.S. 520, 525 (1971); United States v. District Court for Water Div. No. 5, 401 U.S. 527, 529 (1971).

108. For a description of the Colorado system, see note 25 supra.

109. 5 R. ClaRK, supra note $3, \S 414$.

110. See 401 U.S. at 524-25; Dugan v. Rank, 372 U.S. 609, 618 (1963); text accompanying note 36 supra.

111. See United States National Water Commission, supra note 54, at 39.

112. See notes 13-18 supra and accompanying text.

113. 401 U.S. 527, 528-29 (1971); 401 U.S. 520, 522 (1971).

114. Prior to the decisions in Eagle County, Water Division No. Sand Colorado River, the United States had unsuccessfully sought to remove a number of water rights adjudications. See, e.g., In re Bear River Drainage Dist., 267 F.2d 847 (10th Cir. 1959); In re Green River Drainage Area, 147 F. Supp. 127 (D. Utah 1956). But the United States did not assert water 
pears to be unavailable because, like concurrent jurisdiction, it would effectively thwart the Court's goal of comprehensive adjudication of state and federal water rights.

A recent decision by the Wyoming federal district court in the Bighorn Basin litigation supports this conclusion. ${ }^{15}$ The State of Wyoming sued in its own courts for a general adjudication of all water rights in the Bighorn Basin. ${ }^{116}$ After the United States was named as a defendant both in its own proprietary capacity and as trustee for two Indian tribes, ${ }^{117}$ it removed the case to federal district court. The state and various private appropriators moved for remand to state court. ${ }^{18}$ The district court granted the motion, citing the McGarran Amendment, the policies enunciated by the Supreme Court, and various procedural defects in the removal petition. ${ }^{119}$

Finding that the Wyoming plan for adjudication of water rights in the Bighorn Basin qualified as a comprehensive state system, ${ }^{120}$ the court held that considerations of wise judicial administration set forth in Colorado River ${ }^{121}$ applied with equal force to removed cases. ${ }^{122}$

claims based on federal rights in any of these suits. Instead, the federal government's claims were based solely on rights under state law. Cf. $i d$. at 149 (federal reserved rights water claims might serve as a ground for invoking removal jurisdiction).

115. Wyoming v. United States, No. G77-039K (D. Wyo. May 31, 1977) (order remanding to state court pursuant to 28 U.S.C. $\$ 1447$ (1970)). Although reserved rights appear to be at issue, the case does not specifically discuss which types of water rights were being claimed.

116. Wyoming v. United States, No. G77-039K, slip op. at Finding of Fact No. 1; see Wyo. STAT. § 1-1054.1 (Supp. 1977).

117. Wyoming v. United States, No. C77-039K, slip op. at Conclusion of Law No. 1. The district court held that although the Indian tribes might be able to participate in the federal proceeding independently of their trustee under New Mexico v. Aamodt, 537 F.2d 1102 (10th Cir. 1976), this did not affect the state court's capacity to adjudicate their claims under the McCarran Amendment. See Wyoming v. United States, No. C77-039K, slip op. at Conclusion of Law No. 9.

118. Wyoming v. United States, No. C77-039K, slip op. at Conclusion of Law No. 1.

119. Id. at Conclusion of Law No. 10.

120. Id. at Conclusion of Law No. 3.

121. Invoking the litany established by the majority opinion in Colorado River, the district court stated: "The relative inconvenience of the federal forum; the desirability of avoiding piecemeal litigation; the fact that the state court first obtained jurisdiction; the absence of concurrent federal proceedings; and the extensive involvement of state or private claims in this adjudication, all support a remand of this case to the [state court]." Id. at Conclusion of Law No. 5 .

122. Id. The district court stated: "Although this case does not involve an exercise of concurrent jurisdiction, as was the case in Colorado River Water Conservation District . . . the policy factors discussed by the Supreme Court in that case are nevertheless applicable here." Id. By "concurrent jurisdiction" the court here appears to have intended to signify "simultaneous proceedings." The court also noted that under the McCarran Amendment it had concurrent jurisdiction with the Wyoming state courts to hear general water rights adjudications. Id. at Conclusion of Law No. 2. The district court's decision to remand pursuant 
Further, the United States' petition for removal failed to meet the procedural requirements for removal under 28 U.S.C. $\S \S 1441$ and $1446 .{ }^{123}$ These provide that removal petitions be joined by all defendants unless the claim of the defendant seeking removal is "separate and independent." 124 The district court ruled that the federal claims were not separate and independent, ${ }^{125}$ citing Colorado River, ${ }^{126}$ and noted that only one defendant, the federal government, had petitioned for removal. If ultimately vindicated by the Supreme Court, the Bighom Basin court's conclusion that removal is improper under Colorado River unless all defendants prefer federal adjudication represents the death knell for removal jurisdiction in reserved rights cases. ${ }^{127}$

to 28 U.S.C. $\$ 1447$ may not have been proper under subsection (c) of that section, which sets forth the grounds for remand: "If at any time before final judgment it appears that the case was removed improvidently and without jurisdiction, the district court shall remand the case . . . " 28 U.S.C. $\$ 1447$ (c) (emphasis added). If, as argued below, see note 125 infra, the federal rights claims in the Bighorn Basin litigation were "separate and independent" for the purposes of 28 U.S.C. $\$ 1447$ (c), then the court may well have had removal jurisdiction. See note 114 supra. Such a conclusion would render the remand order incorrect but not patently unauthorized-and would therefore render it unreviewable in accord with the prohibition against appellate review contained in 28 U.S.C. § 1447(d). But see Thermtron Prods., Inc. v. Hermansdorfer, 423 U.S. 336, 345-46 (1976) (holding remand on non-jurisdictional ground reviewable and finding it to be reversible error).

123. Wyoming v. United States, No. C77-039K, slip op. at Conclusion of Law No. 7; see 28 U.S.C. $\S \S 1441,1446$ (1970).

124. See 28 U.S.C. § 1441 (c) (1970); C. WRIGHT, supra note 55, § 39.

125. Wyoming v. United States, No. G77-039K, slip op. at Conclusion of Law No. 7. Given the Court's holding in Colorado River that "the relationships among [water rights] are highly interdependent," 424 U.S. at 819 , it is difficult to criticize the Wyoming district court's conclusion that $\S 1441$ (c), which prohibits removal of claims or causes of action that are not separate and independent, see Finn v. American Fire \& Cas. Co., 341 U.S. 6, 13-14 (1951), excludes removal of federal water rights claims to federal court. This is a further repercussion of the Court's fundamental misapprehension of the nature of reserved rights claims, which are necessarily subject to separate and independent adjudication regardless of the forum chosen. See notes 88-91 supra and accompanying text. One can argue that even if the federal rights claims of the United States were not "separate and independent" within the meaning of $\S 1441$ (c), they nonetheless were removable under $\S 1441$ (b), because they arise under "the Constitution, treaties or laws of the United States," with the state law claims coming within the pendent jurisdiction of the federal court. See Swift \& Co. v. United Packinghouse Workers, 177 F. Supp. 511 (D. Colo. 1959); Cohen, Problems in the Removal of a "Separate and Independent Claim or Cause of Action", 46 MinN. L. REv. 1, 25-34 (1961). But see C. WRIGHT, supra note $55, \S 39$.

126. See 424 U.S. at 819.

127. Because water rights of private defendants are lessened by whatever amount of federal reserved water exists, those defendants would probably prefer trial in state courts, which are likely to be hostile to federal claims, see notes 13-20 supra and accompanying text; notes $137-40$ infra and accompanying text. 


\section{G. Restricted Federal Review}

Because Colorado River delegates federal reserved rights cases to state courts, federal appellate review will also be severely curtailed. Formal review of these state court adjudications is available only through a writ of certiorari to the Supreme Court. ${ }^{128}$ Access to the Court is extremely limited, and certiorari may not be granted. Even if the Court elects to review, it may be hampered by the approach of the state court below. ${ }^{129}$

Because certiorari will lie only from a final decision of the highest state court with jurisdiction over the case, ${ }^{130}$ the claimant of federal rights must exhaust state remedies entirely before seeking Supreme Court review. Given the complexity of water adjudications, a state's highest court could easily find error requiring further proceedings below. Thus, substantial investment of time and money may be necessary before a case can even qualify for federal review. While some limited authority exists for invocation of more speedy review to avoid expense and delay, ${ }^{131}$ the water litigation may not fall within the extraordinary class of cases entitled to more immediate review.

\section{JUSTIFICATIONS FOR A FEDERAL FORUM IN RESERVED RightS CASES}

In practical terms, Colorado River means that most, if not all, future adjudication of federal reserved water rights will occur in state courts. ${ }^{132}$ In creating this result, the Court did not confront the strong countervailing interests of the United States and the American Indians in presenting their reserved rights claims to a federal fo-

128. By writs of certiorari the United States Supreme Court may review "[f]inal judgments or decrees rendered by [a state's] highest court . . ." 28 U.S.C. $§ 1257(3)$ (1970). While the Supreme Court can use the appeal process rather than writs of certiorari to review state decisions decreeing treaties invalid, 28 U.S.C. $\$ 1257(1)$ (1970), in adjudicating Indian Winters rights, state courts will only be determining the priority and extent of the rights reserved, not the validity of any treaties granting those rights.

129. For a discussion of the potential negative effects of state-court factfinding in another context, see Amsterdam, Criminal Prosecutions Affecting Federally Guaranteed Civil Rights: Federal Removal and Habeas Carpus Juristiction to Abort State Court Trial, 113 U. PA. L. REv. 793, 798-99, 802-04 (1965) (arguing that biased factfinding by state courts in the South during height of civil rights movement was severely limiting efficacy of Supreme Court review and proposing liberalized removal and habeas corpus proceedings as a pretrial solution).

130. See 28 U.S.C. § 1257 (1970).

131. Sec, e.g., National Socialist Party v. Village of Skokie, 432 U.S. 43 (1977) (immediate appellate review required where first amendment rights restrained); Construction Laborers v. Curry, 371 U.S. 542, 548-49 (1963) (state court preliminary injunction subject to immediate review when jurisdictional conflict with NLRB alleged).

132. See notes 105-31 supra and accompanying text. 
rum. ${ }^{133}$ In his dissent, Justice Stevens noted the anomaly of holding that the United States may not litigate a federal claim in a federal court having jurisdiction over it. ${ }^{134}$ The other dissenting Justices asserted that federal courts are more likely than state courts to be familiar with Indian treaties and federal water law. ${ }^{135}$ They also noted that the Supreme Court had long recognized the importance of leaving Indians free from state jurisdiction and control. ${ }^{136}$ The majority ignored the need to preserve minimal access to federal court, erroneously concluding that state courts were competent to protect these vital federal and Indian interests.

\section{A. The Inadequacy of Primary State Court Control of Reserved Rights Cases}

For a variety of reasons, state courts may prove incapable of protecting the important federal policies that underlie the reserved rights doctrine ${ }^{137}$ and will deprive the United States and Indian groups of vital water rights. The very concept of federal reserved rights is antithetical to the prior appropriation systems in the western states, because reserving unquantified amounts of water can compromise the entire system. ${ }^{138}$ No subsequent appropriator takes with assurance against reduction of the water supply at some future date when the reservation is exercised. In many parts of the West, the assured yearly water supply is virtually exhausted by present appropriations. ${ }^{139}$ Exercise of heretofore unused reserved rights will force some present users to do without water and will deter potential users from settling in the area. To the extent that reserved rights can be narrowly construed, important state economic interests are served:

133. Justice Brennan twice notes the possibility of the choice of forum creating different effects on federal interests. In interpreting the McCarran Amendment to encompass Indian as well as other reserved rights, he states: "Mere subjection of Indian rights to legal challenge in state court . . . would no more imperil those rights than would a suit brought by the Government in district court for their declaration . . ." 424 U.S. at 812. This claim seems too optimistic. See notes 193-208 infra and accompanying text. Later, in limiting the Court's holding, Justice Brennan says that it might be a different case "if the state proceeding were in some respect inadequate to resolve the federal claims." Id. at 820 . But he fails to elaborate on the consequences of this reservation, and the opinion therefore holds little promise for guaranteeing future access as a matter of right to the United States or the Indians to protect their claims and the underlying federal interests.

134. 424 U.S. at 826.

135. Id. at $825-26$.

136. Id. at 826 (quoting McClanahan v. Arizona State Tax Comm'n, 411 U.S. 164, 168 (1973), and Rice v. Olson, 324 U.S. 786, 789 (1945)). ing text.

137. See notes 13-18 supra and accompanying text; notes 160-83 infra and accompany-

138. See notes 13-18 supra and accompanying text.

139. See UNITED StATES NATIONAL WATER COMMISSION, supra note 54, at 272. 
disruption and dislocation incident to termination of existing uses are avoided and actual economic use of water can grow to the limits of supply. Thus, state judges in water rights adjudications will be under strong pressure to rule against the federal government's reserved rights claims. ${ }^{140}$

Apart from concern about bias in the state court system, ${ }^{141}$ additional reasons exist to preserve access to the federal forum. First, federal reserved rights claims are extremely important and their adjudication is likely to have a significant influence on federal policies regarding resource management and environmental protection. ${ }^{142}$ When reserved rights claims are asserted by the government as trustee for American Indians, additional concerns are involved. The disputed rights have an overwhelming effect on the lives of the Indians asserting them, ${ }^{143}$ and their resolution is in part a measure of the sanctity of national commitments made to the Indians. Second, Indian reserved rights present profound questions of federalism ${ }^{144}$ seldom clearly enunciated. In interpreting the existence and magnitude of reserved rights, the federal courts have the necessary familiarity and expertise to resolve complex questions of federal statutory interpretation or of the original Indian-federal water rights agreement. ${ }^{145}$ Deference to this expertise is particularly appropriate when the precise nature of the rights claimed is largely dependent on federal policy choices made when the lands were withdrawn from the public domain. ${ }^{146}$

\section{B. The Protective Jurisdiction Doctrine}

The result of Colorado River is particularly disturbing in light of judicial and scholarly recognition of protective jurisdiction doctrine sanctioning the use of federal jurisdiction to protect federal interests even if state law provides the substantive rule of decision. ${ }^{147}$ Because

140. The federal government's awareness of this institutional pressure on state court judges has been expressed in reserved rights litigation. See, e.g., Brief of Petitioner at 9, United States v. District Court for Eagle County, 401 U.S. 520 (1971).

141. Cf. Amsterdam, supra note 129, at 798-99, 802-04 (danger of provincial state court bias in criminal trials requires liberal pretrial removal and habeas corpus rights).

142. See Cappaert v. United States, 426 U.S. 128 (1976) (protection of rare species of desert fish in Death Valley National Monument); Abrams, supra note 18, at 50052; notes 160-83 infra and accompanying text. See generally cases cited in note 12 supra.

143. See text accompanying note 194 infra.

144. See notes 209-20 infra and accompanying text.

145. See text accompanying notes $135-36$ supra.

146. See Cappaert v. United States, 426 U.S. 128, 138 (1976); notes 160-83 infra and accompanying text.

147. See P. Bator, P. Mishin, D. Shapiro \& H. Wechsler, supra note 85, at 
Colorado River involved federal as well as state substantive law, the reasons for affording a federal forum are even stronger than in traditional protective jurisdiction cases which involve only state substantive law.

The protective jurisdiction doctrine grew out of the early attitude of the Court towards congressional legislation granting original federal jurisdiction in cases involving national banks. In Osborn v. Bank of the United States, ${ }^{148}$ Chief Justice Marshall ruled that article III of the Constitution enabled Congress to guarantee the national banks a federal forum even in cases governed by state law. ${ }^{149}$ Although Marshall's argument relied upon the federal origin of the banks, ${ }^{150}$ later cases justified Osborn's guarantee of access to a federal forum on the pragmatic ground that such jurisdiction was crucial to guard the banks against injury from unsympathetic or insensitive state actions, while providing the uniformity of decision available only in the federal system. ${ }^{151}$

866-70; C. WRIGHT, supra note 55, § 20; Cohen, The Broken Compass: The Requirement that a Case Arise Directly Under Federal Law, 115 U. PA. L. REv. 890-916 (1967). These authors agree on the propriety of the creation of protective jurisdiction, but disagree in their analyses of the constitutional bases for this type of federal jurisdiction. See also the discussion in Justice Frankfurter's dissenting opinion in Textile Workers Union v. Lincoln Mills, 353 U.S. 448, 473-77 (1957).

148. 22 U.S. (9 Wheat.) 738 (1824).

149. As enacted by Congress, the bank's charter provided that the bank "be made able and capable in law . . . to sue and be sued, plead and be impleaded, answer and be answered, defend and be defended, in all state courts having competent jurisdiction, and in any circuit court in the United States." Id. at 817. Chief Justice Marshall held this to mean that Congress intended the bank to have the right to sue or be sued in federal court. Id. Although the jurisdictional issue arose only hypothetically in Osbom, it was squarely presented in a companion case, Bank of the United States v. Planters' Bank, 22 U.S. (9 Wheat.) 904 (1824). See Textile Workers Union v. Lincoln Mills, 353 U.S. 448, 471 (1957) (Frankfurter, J., dissenting).

150. 22 U.S. (9 Wheat.) at 821-23. Chief Justice Marshall ruled that the mere fact of federal jurisdiction was insufficient to justify federal question jurisdiction, $i d$. at 822 , but went on to hold that because Congress had "bestow[ed] upon the being it [had] made, all the faculties and capacities which that being possesse[d], " $i d$. at 827 , every act of the bank was an act under federal law. See also Pacific R.R. Removal Cases, 115 U.S. 1 (1885).

151. See Textile Workers Union v. Lincoln Mills, 353 U.S. 448, 460 (1957) (Burton, J., concurring); International Bhd. of Teamsters v. W.L. Mead, Inc., 230 F.2d 576 (1st Cir. 1956).

In Clearfield Trust Co. v. United States, 318 U.S. 363 (1943), the Court held that the rights and duties of the United States on its issuance of commercial paper are governed by federal rather than state law. Pointing to the substantial federal interests involved, the Court observed: "The issuance of commercial paper by the United States is on a vast scale and transactions in that paper from issuance to payment will commonly occur in several states. The application of state law, even without the conflict of laws rules of the forum, would subject the rights and duties of the United States to exceptional uncertainty. It would lead to great diversity in results by making identical transactions subject to the vagaries of the laws of 
Thus, the Court came to view an essentially protective function-the assurance of a federal forum to vindicate important national interests - as a valid basis for congressional grants of federal jurisdiction. The Court has never retreated from this doctrine, and later Justices have supported the constitutional power of Congress to create federal jurisdiction for these protective purposes. For instance, in National Mutual Insurance Co. v. Tidewater Transfer Co. ${ }^{152}$ three members of the majority recognized this power in upholding a statute granting federal jurisdiction over suits between citizens of the District of Columbia and citizens of other states, despite the absence of a threat to federal substantive policy. ${ }^{153}$ In Textile Workers Union $v$. Lincoln Mills, ${ }^{154}$ two members of the majority interpreted the TaftHartley Act ${ }^{155}$ to afford federal jurisdiction without first finding creation of federal common law and upheld this grant as an instance of protective jurisdiction. ${ }^{156}$

While the Colorado River litigation differs from protective jurisdiction cases because it involves both federal and state substantive law, the fundamental concern warranting protective jurisdiction is present with equal force. Clearly, important federal policies are at stake, policies to which state courts may be insensitive or hostile in water rights controversies. ${ }^{157}$ By erecting barriers such as one-sided factfinding or burdensome procedural rulings, ${ }^{158}$ state courts are capable of precluding effective federal review, even if the Supreme Court has

the several states. The desirability of a uniform rule is plain." Id. at 367; of. Avco Corp. v. Aero Lodge No. 735, Int'l Ass'n of Machinists, 390 U.S. 557, 560-61 (1968) (extending Lincoln Mills to removal actions).

152. 337 U.S. 582 (1949).

153. The case was a 5-4 decision, with the other 2 votes of the majority resting on the conclusion that residents of the District of Columbia were "citizens" for the purpose of article III's diversity clause.

154. 353 U.S. 448 (1957).

155. Labor Management Relations (Taft-Hartley) Act, 29 U.S.C. $\$ \S 141-189$ (1970).

156. Textile Workers Union v. Lincoln Mills, 353 U.S. 448, 460 (1957) (Burton \& Harlan, J.J., concurring). The case was a 7-1 decision, with the other 5 members of the majority upholding the Taft-Hartley Act's grant of federal jurisdiction in certain labor disputes on the ground that the Act was intended to create a federal common law of labor contracts as well as to grant federal jurisdiction. Id at 456. The lone dissenter, Justice Frankfurter, objected both to the view that Taft-Hartley created substantive law and to the exercise of a purely protective jurisdiction in the case. Id. at 473-77 (Frankfurter, J., dissenting). In a footnote, however, he perceived some room for the doctrine of protective jurisdiction in other cases where it is invoked by the federal government and when "federal law [is] in the forefront as a defense." Id. at 475 n.5. Colorado River presented these precise circumstances.

157. See notes 13-18 supra and accompanying text; text accompanying notes $137-40$ supra. 802-04.

158. See, e.g., Cohen, supra note 147 , at $892-93$; Amsterdam, supra note 129, at 798-99, 
time to hear these cases. ${ }^{159}$ The fact that actual questions of federal substantive law are at issue reinforces the need for access to a federal forum. Therefore, the policies of protective jurisdiction should lead to preservation of access to the federal forum in the Colorado River context, to protect federal interests against state hostility, to ensure the fullest review of federal issues and to ensure uniform evaluation of recurrent types of reserved rights claims.

\section{Problems in State Court Adjudication: Mimbres Valley}

Events since Colorado River confirm the fear that state adjudication of federal reserved water rights can injure important federal policies. Mimbres Valley Irrigation Co. v. Salopek ${ }^{160}$ demonstrates the problems which occur when state courts grapple with intricate questions of federal reserved rights. In Mimbres Valley, the New Mexico Supreme Court rendered judgment regarding a federal claim of reserved water rights for a national forest as part of a general state adjudication of water rights in the Rio Mimbres. ${ }^{161}$ The United States had claimed sufficient water to sustain minimum instream flows for forest needs and recreational purposes within the Gila National Forest. ${ }^{162}$ Although the findings of the special master appointed by the district court supported the federal claim, ${ }^{163}$ the state district court reversed the master after the state engineer objected to the findings. ${ }^{164}$ The New Mexico Supreme Court affirmed the lower court's holding that the United States had not reserved water rights

159. See notes 128-31 supra and accompanying text.

160. 90 N.M. 410, 564 P.2d 615 (1977), affd sub nom. United States v. New Mexico, 98 S. Ct. 3012 (1978).

As this Article was going to press, the United States Supreme Court announced its 5-4 decision affirming the New Mexico Supreme Court. While this decision blunts this Article's criticism of the performance of the New Mexico court in Mimbres Valley, it does not wholly vitiate the attack. First, the specific ground upon which that court was criticized was not presented to the Supreme Court. See note 176 infra. Second, comparison of the two opinions reveals the relative want of expertise on the state tribunal in its discussion of congressional intent. Finally, and probably most important, there is little reason to assume that the subsequent performance of state courts will be equally sustainable. Cf. note 196 infra and accompanying text (noting the dismal performance of state courts in Indian cases).

161. The original dispute was between two private parties. The New Mexico state engineer intervened under N.M. STAT. ANN. § 75-4-4 (1953). The complaint-in-intervention sought a general adjudication of water rights in the river, and named all claimants as defendants, including the United States, pursuant to the McCarran Amendment, 43 U.S.C. $§ 666$ (1970). See 90 N.M. at $410-11,564$ P.2d at 615.

162. 90 N.M. at $411-12,564$ P.2d at $615-16$.

163. The master found the United States entitled to 6.0 cubic feet per second for minimum instream flows and recreational purposes. Id. at 411,564 P.2d at 616 .

164. Id. 
for minimum instream flows or for recreation. ${ }^{165}$

In ruling on the United States' reserved rights claims, the Mimbres Valley court purported to adopt the test formulated by the Supreme Court in Cappaert v. United States:

In determining whether there is a federally reserved water right implicit in a federal reservation of public land, the issue is whether the Government intended to reserve unappropriated and thus available water. Intent is inferred if the previously unappropriated waters are necessary to accomplish the purposes for which the reservation was created. ${ }^{166}$

Unfortunately, the New Mexico court badly misapplied the Cappaert standard. In determining the purposes of the Gila National Forest reservation, the court focused on the Organic Act of $1897,{ }^{167}$ in which Congress enumerated the purposes for which the national forests may be used: improving and protecting the forest; securing favorable water flows; and providing a continuous supply of timber. ${ }^{168}$ The Mimbres Valley court construed the Organic Act to exclude recreational use as a congressional purpose ${ }^{169}$ and denied the federal reserved water rights claims. ${ }^{170}$

To demonstrate that the Act's purposes could be construed to include recreational use, the United States pointed to a more recent congressional enactment, the Multiple-Use Sustained-Yield Act of 1960. ${ }^{171}$ This Act stated "that the national forests are established and shall be administered for outdoor recreation, range, timber, watershed, and wildlife and fish purposes." 172 On the basis of questionable readings of the $1960 \mathrm{Act}^{173}$ and a Fourth Circuit opinion, ${ }^{174}$ the Mim-

165. Id.

166. Id. (quoting 426 U.S. 128,139 (1976)). (1976)).

167. Ch. 2, § 1, 30 Stat. 34 (current version at 16 U.S.C. $\S \S 473-478,479-482,551$

168. The pertinent provision is 16 U.S.C. $\S 475$, which provides in part: "No national forest shall be established, except to improve and protect the forest within the boundaries, or for the purpose of securing favorable conditions of water flows, and to furnish a continuous supply of timber for the use and necessities of citizens of the United States; but it is not the purpose or intent of these provisions, or of said section, to authorize the inclusion therein of lands more valuable for the mineral therein, or for agricultural purposes, than for forest purposes."

169. 90 N.M. at $412-13,564$ P.2d at 617-18.

170. Id. at $412,564 \mathrm{P} .2 \mathrm{~d}$ at 618 .

171. 16 U.S.C. $\$ \S 528-531$ (1976); see 90 N.M. at 412,564 P.2d at 618.

172. 16 U.S.C. $\$ 528$ (1976).

173. The court cited a provision in the 1960 Act which states that the purposes set forth under the Act "are declared to be supplemental to, but not in derogation of, the purposes for which the national forests were established as set forth in [the Organic Act of 1897]." Id. see 90 N.M. at 413,562 P.2d at 618 . And then court concluded that this proviso "clearly indicates that Congress did not envision [the purposes of the 1960 Act] as having 
been included in the original Act." Id. A review of the legislative history does not support this interpretation of the proviso. The House Committee's Report on the 1960 Act specified that the language was added as an amendment to the original version of the bill in order to relieve concern that the Act might be interpreted as doing away with timber production and watershed protection as purposes for the establishment of a national forest. See H.R. REP. No. 1551, 86th Cong., 2d Sess. 2, 4, reprinted in [1960] U.S. CODE CONG. \& AD. NEws 2377, 2378, 2380. It is clear that Congress did not view the 1960 Act as in and of itself an extension of the purposes for which the national forests were established. The House Report stated that: "The purpose of this bill is to provide a direction to the Secretary of Agriculture to administer the national forests for multiple use and sustained yield of their several products and services. It would name in a single statute the renewable surface resources for which the national forests are established and shall be administered." Id. at 1, reprinted in [1960] U.S. CoDE CONG. \& AD. NEws 2377. This statement of purpose could mean that Congress viewed the purposes of establishment under the Organic Act of 1897 as including all the purposes of the 1960 Act, the latter serving simply to clarify the obligations of the Secretary of Agriculture. Indeed, there is support for this view specifically for recreational use in a letter from the then acting Secretary of Agriculture, printed in the House Report, which states: "The authority to administer recreation and wildlife habitat resources of the national forests has been recognized in numerous appropriation acts and comes from the authority contained in the act of June 4, 1897 [the Organic Act], to regulate the 'occupancy and use' of the national forests." Id. at 6-7, refrinted in [1960] U.S. CoDE CoNG. \& AD. News 2382. Perhaps the most plausible interpretation of the purpose of the 1960 Act is that it was intended to enumerate and ratify the various uses for the national forests which evolved after passage of the Organic Act of 1897, without close scrutiny of whether such uses were strictly within the bounds of the Organic Act. This is suggested by the following statement in the House Report on the 1960 Act: "The Act of June 4, 1897 . . refers both to watersheds and timber as purposes for which the national forests are established. Through the years by a number of congressional enactments, including appropriations for carrying out specific activities and functions, through court decisions, and through policy directives and statements, the management of the national forests under the principle of multiple use has been thoroughly recognized and accepted. The application of the principle of sustained-yield management has also been thoroughly established. It is thus desirable that the Secretary of Agriculture have a directive to administer the national forests under the dual principles of multiple use and sustained yield." Id. at 2-3, reprinted in [1960] U.S. CODE CONG. \& AD. NEws 2378 . In any event, it is clear that by stating the purposes under the 1960 Act to be "supplemental to, but not in derogation of" the purposes of the Organic Act, see 16 U.S.C. $§ 528$ (1976), Congress could not have intended to state a set of wholly new purposes, because timber and watershed-related purposes are specified in both Acts. See id.; 16 U.S.C. $\$ 475$ (1976). But see 90 N.M. at 413,564 P.2d at 618 ("The fact that Congress declared [the purposes of the 1960 Act] to be 'supplemental to' the purposes for which the national forests were established clearly indicates that Congress did not envision them as having been included in the original Act.").

174. West Va. Div. of Izaak Walton League, Inc. v. Butz, 522 F.2d 945 (4th Cir. 1975). In upholding a conservation group's suit to enjoin the sale of national forest timber to a company which intended to use clear-cutting techniques, the court in lzaak Walton held that the 1960 Act's policies did not serve to overrule "the sale of timber" provisions of the Organic Act of 1897, which stipulated that only portions of "dead, matured or large growth of trees" be sold and that "[s]uch timber, before being sold, shall be marked and designated ..." Ch. 2, § 1, 30 Stat. 35 (repealed 1976); see 522 F.2d at 947-48, 954. The circuit court concluded that "in enacting [the 1960 Act] Congress did not intent [sic] to jettison or repeal the Organic Act of 1897," and that the Act did not ratify the relatively new Forest Service policy of permitting clear-cutting. 522 F.2d at 954; see 90 N.M. at 413,562 P.2d at 618 . In 
clarify nor to expand the purposes for which the Gila National Forest had been established under the Organic Act of 1897. ${ }^{175}$ Therefore, under the Cappaert decision, the federal government had no claim to reserved water rights for recreational purposes. ${ }^{176}$

The court's holding reflects a serious misunderstanding of how federal reserved rights may vest. Although previous cases, including Cappaert, have referred to the purposes at the time of creation as the benchmark for determining federal reserved rights, ${ }^{177}$ reserved rights can also vest as a result of Congress' subsequent expansion of those purposes, ${ }^{178}$ so long as they fall within the authority of the commerce and property clauses of the Constitution. ${ }^{179}$ The only other restriction on such expanded federal claims is that they exist in previously unappropriated waters. ${ }^{180}$ Thus, while the New Mexico Supreme Court may have correctly held that recreational use did not become

applying this holding to the case before it, the Mimbres Valley court ignored an important distinction between the two cases. The Izaak Walton decision involved a purpose clearly antithetical to the special sale of timber provision of the Organic Act, and held that the 1960 Act had not served to repeal that provision. In Mimbres Valley, on the other hand, the court was faced with a purpose-recreational use-which in no way contradicted the general provisions of $\S 475$ of that Act, but was instead either "supplemental" to or included within those provisions.

175. 90 N.M. at 413,562 P.2d at 618 . The court stated: "The Multiple-Use Sustained-Yield Act of 1960 does not have a retroactive effect nor can it broaden the purposes for which the Gila National Forest was established under the Organic Act of 1897." Id. Unless "broaden" is read to mean "clarify," the court's conclusion is either redundant or indicative of the view that the 1960 Act was not intended to allow the Forest Service to claim a 1960 priority for reserved rights incident to the newly expressed purposes.

Interestingly, dicta in Justice Rehnquist's majority opinion reach a similar conclusion by a different method. After construing the later announced purposes to be "secondary," United States v. New Mexico, 98 S. Ct. 3012, 3018 (1978) (emphasis in original), to the favorable water flow purpose of the 1897 Organic Act, Justice Rehnquist notes that withdrawal of water for these purposes might adversely affect water flows. The ineffable conclusion follows that, "Congress intended the national forests to be administered for broader purposes after 1960 but there is no indication that it believed the new purposes to be so crucial as to require a reservation of additional water." Id. at 3021-22.

176. Id. at $412-13,562 \mathrm{P} .2 \mathrm{~d}$ at $617-18$. Although the case was affirmed on certiorari, United States v. New Mexico, 98 S. Ct. 3012 (1978), the issue of whether the Multiple-UseSustained-Yield Act of 1960 was intended to reserve any water for recreational purposes as of the date of its enactment was specifically not presented to the United States Supreme Court. Id. at 3021 n.21.

177. See Cappaert v. United States, 426 U.S. 128, 138 (1976); Colorado River Water Conservation Dist. v. United States, 424 U.S. 800, 825 (1976) (Stewart, J., dissenting); Arizona v. California, 376 U.S. 340, 350 (1964) (decree).

178. In effect, Congress simply again reserves the land in question. The only reason that prior cases, see note 177 supra, have referred to creation of the federal reserves as the benchmark for reserved water rights is that in those cases only one "stage" of reservation had taken place. See, e.g., Cappaert v. United States, 426 U.S. 128, 139 (1976).

179. Cappaert v. United States, 426 U.S. 128, 138 (1976).

180. Id. 
an operative purpose until enactment of the 1960 Act, the opinion failed to broach the crucial question of the existence and amount of unappropriated waters in the Rio Mimbres at that time. To the extent that such waters were available-and the Mimbres Valley opinion contains some evidence to suggest that there may have been such available water ${ }^{181}$ - the United States should have been granted sufficient water rights to satisfy the purpose of recreational use of the Gila National Forest. By failing to recognize this aspect of Cappaert, the New Mexico Supreme Court demonstrated the danger state court adjudication poses to important federal policies. As Colorado River effectively removes similar reserved rights questions from federal forums $^{182}$ the opportunities for inadequate factfinding and for mishandling of delicate federal questions increase. The Supreme Court will be the only resort for federal judicial review of state court adjudications that appear to deal inadequately or incompetently with complex reserved rights issues. ${ }^{183}$

On a different level, it is noteworthy that no state law issues were ruled upon by the New Mexico Supreme Court in Mimbres Valley. ${ }^{184}$ The sole subject of adjudication was the question of federal reserved rights. This situation runs counter to Justice Brennan's assertion in Colorado River that water rights issues are highly interdependent. ${ }^{185}$ Mimbres Valley shows that reserved rights issues often receive distinct treatment within the unitary state system, confirming the position of the dissenters in Colorado River ${ }^{186}$ and discrediting the notion that judicial economy will be served by denial of the federal forum in Winters rights cases. ${ }^{187}$

181. The court noted that the appeal had also raised the question of whether water rights used by permittees of the United States Forest Service should be adjudicated under state law provisions for prior appropriations or whether they were to be charged to the general federal allocation. The court held that since the permittees were using water which, under its holding, the federal government had no rights in, the permittees must perfect their claims in accordance with state law, as prior appropriators. See 90 N.M. at 414, 564 P.2d at 619. If the water rights claimed by these permittees were unappropriated as of enactment of the Multiple-Use Sustained-Yield Act of 1960, then such rights should have vested at that time.

182. See notes 105-31 supra and accompanying text.

183. See notes 105-31 supra and accompanying text.

184. The question of allocation of permittee rights, see note 181 supra, might have presented questions of state law under the doctrine of prior appropriation, had the court ruled such rights to be independent of the government's reserved rights claims. See 90 N.M. at 414,564 P.2d at 619.

185. See 424 U.S. at $819-20$.

186. See id. at 825-26 (Stewart, J., dissenting).

187. There are, however, some advantages in having all rights determined by a specialized tribunal. Although federal reserved rights are different in kind from state appropria- 


\section{The NeEd For a Federal Forum in INDIAN Reserved Rights Cases: The UniQue Status of INDian Rights}

The significance of the Colorado River decision extends beyond its emphasis upon state adjudication of federal reserved water rights, for the rights at issue belonged to Indian claimants. In the majority opinion, Justice Brennan failed to consider the potential consequences of relegating Indian rights claims to the state courts. The opinion restricted itself to considering "whether the McCarran Amendment provided consent to determine federal reserved rights on behalf of Indians in state court."188 This narrow focus on statutory intent ignores problems unique to Indian ownership of federal reserved water rights.

Justice Brennan advanced two arguments to support his conclusion that Indian water rights merit the same treatment afforded to other federal reserved rights claims. Eagle County held that, under the McGarran Amendment, federal reserved water rights could be adjudicated in state court, and, in dictum, said that this was true of all other reserved rights which the government "otherwise" owned. ${ }^{189}$ Justice Brennan in the Colorado River opinion blandly extended that logic to apply to adjudication of Indian rights, reasoning that a contrary decision would violate the McCarran Amendment's purpose by hindering state efficiency. Because the federal interests in maintaining federal jurisdiction, however, are so great, ${ }^{190}$ the majority would have to argue that confining the whole litigation to state courts is vastly more efficient than federal determination of the magnitude and priority of federal reserved rights and subsequent state integration of these rights into a unified system for administration of water rights. As the dissent in Colorado River explained, such a showing cannot be made. The existing Colorado scheme is bifurcated; one proceeding quantifies and gives a priority date while the other proceeding integrates quantified claims. Thus, the dissent concluded,

[I]f this suit were allowed to proceed in federal court the same procedures would be followed, and the federal court decree would be incorporated into the state tabulation, as other federal court de-

tive rights, their quantification depends to some extent on estimating the appropriate amount of water required to support the intended level of consumptive use. A specialized state tribunal can probably make this determination more easily than could the federal judiciary. For a discussion of the difficulties of such determinations, see Ranquist, supra note 18, at 659-62. In the past, some federal courts have appointed a master to ascertain water requirements. See, e.g., Arizona v. California, 373 U.S. 546 (1963).

188. 424 U.S. at 809.

189. United States v. District Court for Eagle County, 401 U.S. 520, 524 (1971).

190. See notes 193-200 infra and accompanying text. 
crees have been incorporated in the past. Thus, the same process will occur regardless of which forum considers these claims. ${ }^{191}$

Absent a demonstration of significant efficiency gains, the majority in Colorado River failed to meet the traditionally high burden associated with abdication of federal judicial duties. ${ }^{192}$ Moreover, many factors unique to Indian reserved water rights demand special treatment of such claims. These include the possibility of state court bias, Indian perceptions of state courts, the historical basis for special treatment of Indians, and the federal trusteeship of Indian property.

\section{A. The Possibility of State Bias}

Both majority and dissent in Colorado River avoided openly acknowledging that state courts might be biased against Indians. An awareness of this possibility, however, is apparent in both opinions. The majority states:

[T]he Government's argument [as Trustee for the Indians] rests on the incorrect assumption that consent to state jurisdiction for the purpose of determining water rights imperils those rights . . . . Mere subjection of Indian rights to legal challenge in state court, however, would no more imperil those rights than would a suit brought by the Government in district court for their declaration. ${ }^{193}$

The dissent in turn responds:

It is not necessary to determine that there is no state-court jurisdiction of these claims to support the proposition that a federal court is a more appropriate forum than a state court for determination of questions of life-and-death importance to Indians. This Court has long recognized that " $[t]$ he policy of leaving Indians free from state jurisdiction and control is deeply rooted in the Nation's history." 194

Thinly veiled below the surface of both opinions is a recognition of the multi-faceted problem of potential state-court bias against Indians. Although it is difficult to establish there is such a bias, an amicus brief, filed by the Southern Ute Indian Tribe, specifically asserted that such a bias exists. ${ }^{195}$ The brief, however, did not present

191. 424 U.S. at 825 (Stewart, J., dissenting).

192. See, e.g., Cohens v. Virginia, 19 U.S. (6 Wheat.) 264, 403 (1821) ("We have no more right to decline the exercise of jurisdiction which is given, than to usurp that which is not given. The one or the other would be treason to the constitution.") (Marshall, C.J.).

193. 424 U.S. at 812.

194. Id. at 826 (Stewart, J., dissenting).

195. Brief of Amicus Curiae, Southern Ute Indian Tribe, at 35-40, Colorado River Water Conservation Dist. v. United States, 424 U.S. 800 (1976) [hereinafter Indian Amici Brief]. The Indian amici find some support in the Supreme Court's statement in an 1886 decision, that the Indian tribes "owe no allegiance to the States and receive from them no 
persuasive evidence to support that charge. For example, it pointed to a series of state decisions adverse to Indian property or sovereignty interests that were subsequently reversed by unanimous decisions of the United States Supreme Court. ${ }^{196}$ The amici, however, failed to consider how many state court cases were settled agreeably; moreover; they did not state the grounds upon which reversal was urged and granted. ${ }^{197}$ In its most compelling demonstration of state-court bias, the Indian brief examined the case of United States $v$. Washington, ${ }^{198}$ in which state injunctive powers were used to aid discriminatory misapplication of state law. The only meaningful relief available to the Indians was in a federal court. Although the case demonstrates that state courts can be biased against Indians, ${ }^{199}$ the question of the extent and frequency of such bias remains open. ${ }^{200}$ Even if state courts are not actually biased, the states do have strong interests in acquiring jurisdiction over Indian water rights and none of the responsibility to protect Indian interests carried by the federal government. Thus, even if bias is not present, state courts may be insensitive to Indian reserved water rights claims.

\section{B. Indian Perception of State Courts}

Although evidence may not conclusively demonstrate that state courts are inherently biased against Indian claims, Indians may nonetheless believe themselves disfavored by state courts. This fear of biased state-court adjudication of Winters rights is an important reason for rejection of virtually exclusive state-court adjudication. ${ }^{201}$ Modern jurisprudential theorists have argued that the assessment of

protection. Because of the local ill feeling, the people of the States where they [the Indians] are found are often their deadliest enemies." United States v. Kagama, 118 U.S. 375 (1886).

196. Indian Amici Brief, supra note 195, at 36-38.

197. See id.

198. 384 F. Supp. 312 (W.D. Wash. 1974), affd, 520 F.2d 677 (9th Gir. 1975), cert. denied, 423 U.S. 1086 (1976).

199. See Indian Amici Brief, supra note 195, at 38-40 (discussion of Washington).

200. One can be confident that bias against Indians is not limited to those rare occasions captured in documentary record. See Ranquist, supra note 18, at 699 \& n.258. On the other hand, the possibility of bias is probably insufficient reason to disqualify state courts from every proceeding involving Indians.

201. As one commentator states in a discussion of bias and prejudice in the diversity context: "Actual prejudice aside, there remains the matter of the appearance of prejudice, or the belief of an out-of-state party that he may be the victim of prejudice. As the ALI Study argued, the out-of-stater may be more willing to accept defeat with good grace, and not to attribute it to local bias, in a federal than in a state court. This is a matter of no little consequence in a nation that prides itself not only on doing justice, but on being seen to do justice." Shapiro, Federal Diversity Jurisdiction: A Survey and a Proposal, 91 HARv. L. REv. 317, 330 (1977) (emphasis in original) (footnote omitted). 
the fairness of a legal system must include an exploration of the perceptions of those subject to that system. ${ }^{202}$ Without attempting to canvass the strengths and weaknesses of this argument, one can still use it as a starting point for considering the Indian's view of state courts. Absent a strong countervailing interest, a just society will try to remedy a condition which any substantial group perceives as unfair or discriminatory in order to maintain its reputation for impartiality. ${ }^{203}$

Indians clearly fear state court hostility to rights which are of paramount importance to their physical and cultural survival. ${ }^{204}$ Indian experience in state courts has led to distrust; the group now views the state court as an agency of repression. ${ }^{205}$ As one Indian speaker testified at Senate hearings in 1974: "It has . . . become abundantly clear that the western States are interested in subjecting the Indian tribes

202. Cf. Michelman, Property, Ulility, and Faimess: Comments on the Ethical Foundations of "Jusl Compensalion" Law, 80 HARv. L. Rev. 1165, 1218-24 (1967) (even sound utilitarian denial of compensation may demoralize society if it appears unfair to common citizen). See generally J. RAwLS, A THEORY OF JUSTICE (1971). The danger of perceived prejudice is especially great when the perceiver is a traditionally disfavored social group.

203. Professor Michelman perhaps best sums up the appropriate inquiry: "Rawls's theory attracts our attention because it is concerned with inequalities in the treatment-the quota of powers, honors, and incomes-received by individuals under collectively maintained arrangements. A cogent attempt is made to clarify the idea of justice as the special virtue of social arrangements within which such inequalities become acceptable. They are said to be acceptable-the arrangements producing them are deemed just-if those arrangements are consistent with principles which could command the assent of every member of a group of rational, self-regarding persons, convening under circumstances of mutually acknowledged equality and interdependence, to hammer out principles by which they will judge complaints against whatever rules and institutions may come to characterize their association. All of these persons are presumed to be aware that each is powerless either to impose his preferences on any other or to claim for himself, in advance, any particular position which may be constituted by a rule or institution. Social practices, then, are to be judged by principles which a person would favor if he had to assume that he might occupy the least advantageous position distinguishable under any rule or institution which might emerge." Michelman, supra note 202 , at 1219. The relevant question, therefore, is whether one placed in the position of Indians, the group disadvantaged by the policy choice implicit in Colorado River, would reasonably insist on protection against that predicament.

204. See, e.g., Indian Water Rights: Hearings Before the Subcomm. on Indian Affairs of the Senale Comm. on Interior and Insular Affairs, 93d Cong., 2d Sess. 77 (1974) [hereinafter cited as Waler Rights Hearings] (statement of Carl Todacheenee, Ghairman, Resources Committee, Navajo Tribal Council). Cf. Berry, The Importance of Perceptions in the Determination of Indian Water Rights, 10 WATER Resources BulL. 137 (1974) (discussing political conflicts and incongruent perceptions of Indian legal rights of Indians, federal administrators and state allocators).

205. For a parallel claim concerning the Black experience with both state and federal jurisdiction, see Burns, Black People and the Tyranny of American Law, 407 ANNALS AM. AGAD. PoltTical \& SOC. Sar. 156 (1973). 
to hostile State courts to adjudicate Indian water rights." ${ }^{206}$ Attendant upon the perceived hostility is a sense of injustice and unfairness.

The voiced societal interest competing with the Indian's perceptions is the benefit of giving certainty to claimed state water rights in the arid West. But society will gain this benefit, however, wherever the Indian claims are determined. ${ }^{207}$ Thus, the only benefit of choosing the state forum is administrative convenience, and even this benefit may be of limited value. ${ }^{208}$ When the interests are balanced against one another, the benefits of administrative convenience simply do not justify the subjection of Indians to perceived hostility and injustice.

\section{Historical Basis for Special Treatment of Indians}

American Indians historically have received special treatment from the federal government. As a result of the original status of Indian tribes as sovereignties, legal relations with Indians were instituted by treaty. The United States Constitution ${ }^{209}$ required that governmental interaction with the Indians take place on the federal level. More significantly, Congress has traditionally insulated the Indians from state governmental and judicial control. ${ }^{210}$ The executive branch of the federal government has established a special trust relationship with respect to Indian property and has developed a massive bureaucracy concerned with Indian problems. This distinct status, independent of traditional state jurisdiction, received early judicial sanction and congressional acceptance ${ }^{211}$ which have continued virtually unbroken. ${ }^{212}$

The federal jurisdictional interest in suits involving Indians also receives unequivocal judicial support. For example, in Oneida Indian Nation v. County of Oneida, ${ }^{213}$ a unanimous Supreme Court held that an ejectment action brought by Indians, unlike suits by non-Indian

206. Water Rights Hearings, supra note 204, at 46 (statement of Wendell Chino, President, Mescalero Apache Tribe).

207. See notes 191-92 supra and accompanying text.

208. See notes 88-91 supra and accompanying text.

209. U.S. ConsT. art. I, $\S 8, \mathrm{cl} .3$ ("The Congress shall have power . . . [t]o regulate Commerce . . . with the Indian Tribes . . ."). See, e.g., Hamilton v. MacDonald, 503 F.2d 1138,1149 (9th Cir. 1974) (Congress possesses exclusive regulatory power over Indian tribes).

210. See, e.g., Indian Intercourse Act of June 30, 1834, ch. 161, 4 Stat. 729 (current version in scattered sections of 25 U.S.C.).

211. See, e.g., Worcester v. Georgia, 31 U.S. (6 Pet.) 515 (1832); Act of Apr. 10, 1869, ch. $15, \S 4,16$ Stat. 40 (current version in scattered sections of 25 U.S.C.).

212. See McClanahan v. Arizona Tax Comm'n, 411 U.S. 164, 168 (1973) (quoting Rice v. Olson, 324 U.S. 786, 789 (1945)).

213. 414 U.S. 661 (1974). 
claimants, conferred federal question jurisdiction. In support of the Oneida ruling the Court pointed out, "state authorities have not easily accepted the notion that federal law and federal courts must be deemed the controlling considerations in dealing with the Indians." 214

\section{Federal T'rusteeship of Indian Property}

The nature of the federal trusteeship of Indian property buttresses the conclusion that adjudication of Indian Winters rights claims should not be relegated to the state courts. The executive is not the only branch with obligations to the Indians; the fulfillment of the federal trusteeship requires the involvement of the other branches of government as well. The cooperation of Congress is needed, as is superintendence by the judiciary. In light of this tripartite nature of the trusteeship, it is surprising that the Colorado River decision determined congressional intent to include Indian rights in the McGarran Amendment. ${ }^{215}$

The trusteeship may also bear on Colorado River in a more subtle way. A court adjudicating Indian Winters claims may have to consider the diligence with which the federal government has exercised its trusteeship. ${ }^{216}$ The Indians charge that breaches of trust have repeatedly occurred when Congress has appropriated funds for reclamation water projects on streams in which Indians have Winters claims without providing sufficient capital to the Indians for develop-

214. Id. at 678. The Court was careful to reaffirm the general principle that controversies over land do not raise federal questions for jurisdictional purposes solely because original title may have derived from the United States. The Court found a federal question because of the not insubstantial claim that federal law protects, and has continuously protected from "the time of the formation of the United States, possessory right to tribal lands, wholly apart from the application of state law principles which normally and separately protect a valid right of possession." Id. at 677.

215. Indeed, even as construed in the Colorado River case, the McCarran Amendment does not grant exclusive jurisdiction over Indian reserved water rights to the states. See note 35 supra and accompanying text. Nevertheless, the Court's interpretation of the Amendment vests forum choice solely in the hands of the non-Indian parties, so it is now within their power to frustrate an earlier choice of forum by Indian claimants.

216. Although the Supreme Court has noted there are "high standards for fair dealing required of the United States in controlling Indian affairs," United States v. Tillamooks, 329 U.S. 40, 47 (1946), one federal circuit judge has noted: "From the very beginnings of this nation, the chief issue around which federal Indian policy has revolved has been, not how to assimilate the Indian nations whose lands we usurped, but how best to transfer Indian lands and resources to non-Indians." United States v. Ahtanum Irrigation Dist., 236 F.2d 321, 337 (9th Cir. 1956) (quoting Van de Mark, The Raid on Reservations 48 HARPER's MaGAzINE 48, 49 (1956)). 
ment of their rights. ${ }^{217}$ The federal government may also be violating its trusteeship duties by failing to provide Indians with the legal and technical assistance necessary to participate effectively in Winters rights quantification proceedings. ${ }^{218}$

When litigation of Winters rights involves a claim of breach of federal trust, even an absolutely unbiased state court water judge may be totally unfamiliar with the nature of that federal trust responsibility. ${ }^{219}$ In addition, state courts lack authority to compel performance of federal trust responsibilities relating to case preparation. ${ }^{220}$ Thus, the trusteeship analysis, like the perceptions and historical analyses, demonstrates that the adjudication of Indian Winters rights claims should not be relegated to the state courts.

217. The Indians, lacking money to make use of the appropriable water, must helplessly watch non-Indian state law appropriators flourish. See, e.g., Water Rights Hearings, supra note 204, at 4-6, 9, 48, 56-58 (testimony of various speakers representing Indian interests). For a discussion of how the increased emphasis on coal extraction in the West and the concomitant need for large quantities of water threaten Indian reserved rights, see Veeder, Confscation of Indian Winters Rights in the Upper Missouri River Basin, 21 S.D.L. REv. 282 (1976). Were Indians to exercise their water rights, conflict with other appropriators would certainly arise. Those charged with federal water planning have recognized that "[t]he most intractable problem . . . is the conflict between existing non-Indian uses and newly initiated Indian withdrawals. While the Indians often have legal superiority to make use of water, a later initiated Indian use often would disrupt preexisting non-Indian uses representing large Federal, State, and private investments." UNITED STATES NATIONAL WATER COMMISSION, supra note 54, at 163-64. As more non-Indian appropriators invest in reliance on state water rights which are legally inferior to the dormant Indian Winters rights, there is less Indian hope of ever obtaining use of that water. Combined with the previous failure of the federal government to aid Indian economic development dependent on water use, the government's hesitancy to disrupt massive prior investment justifies the Indians' fear that their Winters rights will atrophy. See, e.g., Water Rights Hearings, supra note 204, at 6 (testimony of Robert Lewis, President, National Tribal Chairmen's Association).

218. The federal government must upgrade the level of legal and technical assistance given to the Indians to enable them to participate successfully in quantification hearings. Absent such preparation for adjudication, even the interpretation of the McCarran Amendment suggested in this Article represents a grave threat to Indian Winters rights. Under the view of both this Article and the Court in Colorado River, non-Indian parties can force immediate quantification of the Winters rights; the crucial disagreement involves whether federal courts should be available to make these determinations if the Indians would prefer them. Since non-Indians may be the moving parties for quantification in either case, however, it is likely that Indian claimants often will have inadequate opportunity to prepare for litigation. See Water Rights Hearings, supra note 204, at 48 (statement of Wendell Chino, President, Mescalero Apache Tribe) (requesting 10-year moratorium on Winters rights adjudication to allow for adequate inventory).

219. See, e,g., Water Rights Hearings, supra note 204, at 15 (statement of Frank Tenorio, Secretary, All Indian Pueblo Council) (state judges adjudicating Winters claims "are not cognizant of what the original treaty was or what the obligations of the trustee are and they run roughshod ....'”.

220. P. BATOR, P. Mishkin, D. Shapiro \& H. Wechsler, supra note 85, at 420-31; Redish \& Woods, Congressional Power to Contest the Jurisdiction of Lower Federal Courts: A Critical Review and a New Synthesis, 124 U. PA. L. Rev. 45, 93 (1975). 


\section{CONCLUSION}

This Article has argued that the interests favoring federal adjudication of reserved rights claims outweigh the actual efficiency gains, if any, that will result from relegating these claims to the state courts. The interests favoring a federal forum are especially strong when reserved rights are being claimed on behalf of American Indians. Although the Court's decision in Colorado River begins to close the door on concurrent jurisdiction for Indian claims, the trend can still be reversed. Ideally, the Court should reexamine Colorado River, both by reconsidering whether all reserved rights claims can be separated from the determination of prior appropriation rights and by explicitly weighing the long-standing unique status of American Indians. Alternatively, Congress should intervene and clarify the McCarran Amendment so as to provide specific guarantees of access to the federal forum. ${ }^{221}$

Short of such major reforms, the federal district courts will be left to strike a new balance on a case-by-case basis, by declining to dismiss or remand Indian reserved rights claims. While lower courts cannot directly defy the policies set forth by the Supreme Court in Colorado River, they can narrow the opinion's impact by drawing factual and procedural distinctions in later cases. ${ }^{222}$ Otherwise, these re-

221. Unfortunately, current legislation seems to be moving in the wrong direction. A bill recently proposed by Representative Meeds of Washington, see 123 CoNG. REC. H12,195-96 (daily ed. Nov. 3, 1977), would require the filing of suits for adjudication and quantification of all federal reserved rights for the use and benefit of Indian reservations within 5 years of its enactment. All claims not filed within that period would be extinguished. Moreover, the bill would limit such claims, "if proven, to be quantified in the amount of highest annual actual permissible uses, as defined in this Act in any of the five years preceding January 1, 1977." Id. While not only severely limiting the scope of Indian reserved rights claims, the proposed bill would leave the existing scheme of McCarran Amendment jurisdiction unaltered. See id.

222. Indeed, Justice Brennan's opinion was limited to a justification of the district court's dismissal "in this particular case." 424 U.S. at 820. He added, "We need not decide, for example, whether, despite the McCarran Amendment, dismissal would be warranted if more extensive proceedings had occurred in the District Court prior to dismissal, if the involvement of state water rights were less extensive than it is here, or if the state proceeding were in some respect inadequate to resolve the federal claims." Id. The first and third examples offer little real prospect for distinguishing later cases, as long as defendants move to dismiss or remand promptly and state legislatures act to conform their adjudicatory proceedings to the Colorado model. See notes 105-31 supra and accompanying text. The second example, which concerns the extent of state involvement, might be a valid ground of distinction where the United States seeks only federal adjudication of federal reserved rights, as opposed to determination of both reserved rights and rights granted under state law, such as was involved in Colorado River. See 424 U.S. at 805 . Finally, in states considering bills which would establish general adjudication systems, see notes 111-23 supra and accompanying text, the best interests of the United States and Indian claimants would be served by prompt filing 
served rights claims will be relegated to state courts that will not adequately consider their merit-courts in which the Indians have justifiably little faith. exclusion from the federal courts once the states' general systems are established. 